\title{
Geochemistry of Eocene-Early Oligocene low- temperature crustal melts from Greater Himalayan Sequence (Nepal): a nanogranitoid perspective
}

\author{
Omar Bartoli $^{1^{*}}$, Antonio Acosta-Vigil ${ }^{2}$, Bernardo Cesare ${ }^{1}$, Laurent Remusat ${ }^{3}$, \\ Adriana Gonzalez-Cano ${ }^{3}$, Markus Wälle ${ }^{4}$, Lucie Tajčmanová ${ }^{5}$, Antonio \\ Langone ${ }^{6}$ \\ ${ }^{1}$ Dipartimento di Geoscienze, Università degli Studi di Padova, Padova, Italy \\ ${ }^{2}$ Instituto Andaluz de Ciencias de la Tierra, CSIC-Universidad de Granada, Spain \\ ${ }^{3}$ Muséum National d'Histoire Naturelle, Sorbonne Université, UMR CNRS 7590, IRD, Institut de \\ Minératogie, de Physique des Matériaux et de Cosmochimie, IMPMC, Paris, France \\ ${ }^{4}$ REAIT, CRC and CFI Services (CCCS), Memorial University of Newfoundland, Canada \\ ${ }^{5}$ Institute of Earth Sciences, Heidelberg University, Germany \\ ${ }^{6}$ Istituto di Geoscienze e Georisorse, C.N.R.University of Pavia, Pavia, Italy \\ * corresponding author: omar.bartoli@ unipd.it, +390498279832
}

\begin{abstract}
Despite melt inclusions in migmatites and granulites have provided a wealth of information on crustal anatexis in different geological scenarios, yet a complete compositional study (including trace elements and $\mathrm{H}_{2} \mathrm{O}$ ) is missing for the Himalayas. In this contribution, we focus on nanogranitoids occurring in peritectic garnet of migmatites from Kali Gandaki valley in central Nepal (Greater Himalayan Sequence, GHS). Their microstructural position proves that these melts were produced at $650-720^{\circ} \mathrm{C}$ and $1.0-1.1 \mathrm{GPa}$, during the Eohimalayan prograde metamorphism (41-36 Ma) associated to crustal thickening. Nanogranitoid compositions (mostly granodiorites, tonalities and trondhjemites) resemble those of experimental melts produced during $\mathrm{H}_{2} \mathrm{O}$-present melting of metasedimentary rocks. They have variable $\mathrm{H}_{2} \mathrm{O}$ concentrations (6.5-14.4 wt\%), which approximate the expected minimum and maximum values for crustal melts produced at the inferred $\mathrm{P}-\mathrm{T}$ conditions. These compositional signatures suggest that melt formation occurred in the proximity of the
\end{abstract}


$\mathrm{H}_{2} \mathrm{O}$-saturated solidus, in a rock-buffered system. The low to very low contents of $\mathrm{Zr}$ (3-8 ppm), Th (0.1-1.2 ppm) and LREE (4-11 ppm) along with the weak to moderate positive Eu anomalies $\left(\mathrm{Eu} / \mathrm{Eu}^{*}=1.2-3.3\right)$, the high B concentrations (200-3400 ppm) and the high U/Th ratio (up to 21) point to the lack of equilibration between melt and accessory minerals and are consistent with melting of plagioclase at low temperature. Kali Gandaki nanogranitoids have recorded the beginning of melting in a $\mathrm{H}_{2} \mathrm{O}$-present scenario that, in other GHS localities, may have produced voluminous crustal melts. We demonstrate that compositional comparison with nanogranitoids may be useful to reconstruct the petrogenesis of Eohimalayan granitoids.

Keywords: Nanogranitoids, Greater Himalayan Sequence, low-T crustal melts, $\mathrm{H}_{2} \mathrm{O}$-present melting 


\section{Introduction}

2 The Himalaya mountain belt is the largest active collisional orogen on our planet and is an

3 ideal natural laboratory for investigating orogenic processes (Kohn 2014). This mountain

4 chain has resulted from collision between India and Asia at c. $59 \mathrm{Ma}$ (Hu et al. 2016). The

5 structural and metamorphic evolution of this orogenic belt is divided into two main phases

6 (Hodges 2000): an Eocene-Late Oligocene Eohimalayan phase during which crustal

7 thickening occurred and most metamorphic rocks reached peak conditions in the kyanite

8 stability field, and an Early Miocene to present Neohimalayan phase characterized by

9 formation of sillimanite-bearing rocks and leucogranites which intruded the higher portions

10 of the Himalayan belt - the so called "Himalayan leucogranites" - whose largest plutons

11 formed at c. $21 \mathrm{Ma}$ (Harrison 2006).

Himalayan leucogranites and the associated Miocene migmatites have been investigated for decades (Weinberg 2016 and references therein). A number of works have established that Miocene anatexis and leucogranite formation occurred by fluid-absent melting of muscovite during decompression (e.g., Inger and Harris 1992; Pognante and Benna 1993; Harris et al. 1995; Harris and Massey 1994; Davidson et al. 1997). Recently, 17 some works have argued that decompression was a consequence rather than a cause of 18 melting (e.g., Rubatto et al. 2013) and the recent review paper by Weinberg (2016) has demonstrated the complexity of Neohimalayan anatexis which records differences in P-T$\mathrm{X}_{\mathrm{H} 2 \mathrm{O}}$ conditions, timing and duration across the Himalayas. occurred during crustal thickening (i.e., the Eohimalayan anatexis), partly because of 23 pervasive Miocene thermal overprint. Where evidence exists, the majority of works have 24 dealt with the age and $\mathrm{P}-\mathrm{T}$ conditions of high-grade metamorphic processes (e.g. Hodges et 
al. 2011; Rubatto et al. 2013; Palin et al. 2014; Wang et al. 2013; 2015; Iaccarino et al. 2017),

without shedding light on the composition of crustal melts which, in turn, may provide important, and otherwise impossible to retrieve, information on melting mechanisms (e.g., Acosta-Vigil et al. 2010, 2012, 2017; Sawyer 2010, Carvalho et al. 2016, 2017, 2018;

Weinberg and Hasalová 2015a). For instance, an unusual Ca-rich leucogranite of Late

Oligocene age (c. $27.5 \mathrm{Ma}$ ) was considered to provide a rare insight into the pre-Miocene melting associated to crustal thickening (Zhang et al. 2004).

In this contribution, we present for the first time the trace element and $\mathrm{H}_{2} \mathrm{O}$ content of melt inclusions (i.e., nanogranitoid inclusions or simply nanogranitoids; Cesare et al. 2015; Bartoli et al. 2013a, 2016a; Ferrero and Angel 2018) from the Himalaya mountain belt. Nanogranitoids come from the Greater Himalayan Sequence - which constitutes the highgrade crystalline core of the orogen- and are present in a microstructural position that clearly proves an Eohimalayan origin for these droplets of crustal melt (Carosi et al. 2015).

\section{Geological background and sampling}

From south to north, the Himalayan belt is divided into four tectonic units -Sub-

Himalayas molasses, Lesser Himalayan Sequence, Greater Himalayan Sequence (GHS) and

Tethyan Himalayan Sequence (THS) - which are separated by important tectonic structures, i.e. Main Boundary Thrust, Main Central Thrust (MCT) and South Tibetan Detachment System (Hodges 2000 and references therein; Fig. 1a). The GHS is a 20-30 km thick sequence of medium- to high-grade metamorphic rocks and represents the metamorphic core of the Himalaya (Searle and Godin 2003). Several levels of tectono-metamorphic discontinuities were identified within the GHS (Carosi et al. 2018).

The sample under investigation comes from the $\mathrm{N}-\mathrm{S}$ trending Kali Gandaki valley of central Nepal (Fig. 1b), one of the most classic study areas of the Himalaya (see Carosi et al. 
2014 and references therein). Here, GHS reaches a structural thickness of 10-15 km (Godin

53 2003), shows a NE-dipping prominent high-grade foliation with SW-verging isoclinal folds

54 (Brown and Nazarchuk 1993; Godin 2003; Kellett and Godin 2009; Searle 2010) and can be

55 subdivided in three units (Searle and Godin 2003; Searle 2010): the lowest Unit 1 is

56 represented by kyanite-bearing gneisses and migmatites, the Unit 2 consists of

57 clinopyroxene-garnet-amphibole-bearing calcsilicate gneisses, whereas Unit 3 is made of 58 orthogneisses and minor metapelites.

59 The nanogranitoid-bearing garnet crystal selected for this study has been collected 60 from the debris at the base of an outcrop of kyanite-bearing migmatitic paragneiss (lower part 61 of Unit 1), located close to Titar village (North of Dana village, Fig. 1b). In this outcrop, 62 gneisses have a porphyroblastic texture and contain quartz + plagioclase + biotite + garnet + 63 kyanite + white mica (Fig. 2a). Monazite, xenotime, apatite, zircon, tourmaline, rutile, 64 ilmenite and pyrite are present as accessory minerals. Ilmenite is present in the matrix, 65 whereas rutile occurs only as relict cores in the former mineral and within garnet and kyanite 66 (Carosi et al. 2015; Iaccarino et al. 2015). Tonalitic leucosomes, mainly made of quartz + 67 plagioclase + kyanite, occur parallel to the main foliation defined by biotite and white mica 68 (Fig. 2a; Iaccarino et al. 2015). Garnet crystals both in the rock matrix and collected at the 69 base of the outcrop contain analogous mineral and melt inclusions and show exactly similar 70 compositional features (Carosi et al. 2015; Iaccarino et al. 2015), indicating that the dispersed 71 investigated garnet come from adjacent Ky-bearing migmatites.

72 Phase equilibria modeling of migmatitic paragneisses indicates peak conditions of $73 \quad 710-720^{\circ} \mathrm{C}$ and $1.0-1.1 \mathrm{GPa}$, whereas the application of $\mathrm{Zr}$-in-rutile thermometer yielded 74 temperatures of $\approx 650-720{ }^{\circ} \mathrm{C}$ (at $\mathrm{P}=1.1 \mathrm{GPa}$ ), interpreted as prograde temperatures (Fig. 2b; 75 Iaccarino et al. 2015). These rocks underwent anatexis with the subsequent formation of 76 leucosomes close to peak conditions, and then decompression and cooling to $650-670{ }^{\circ} \mathrm{C}$ and 
0.7-0.8 GPa (Iaccarino et al. 2015). The calculated amount of melt generated at peak conditions is $\approx 7.5$ vol\% (Fig. $2 b$ ), approaching the critical threshold for melt interconnection and migration $(\approx 7$ vol\%; Rosenberg and Handy 2005). As a matter of fact, melt accumulation is observed in leucosomes and in dilational structures, whose total volume is far more than the predicted amount of melt at peak conditions (Fig. 2a) (see Iaccarino et al. 2015).

In situ $\mathrm{U}-\mathrm{Th}-\mathrm{Pb}$ dating of monazite has constrained the partial melting process at $\mathrm{c}$. 41-28 Ma (Fig. 2b; Carosi et al. 2015; Iaccarino et al. 2015). On the basis of these and previous geochronological constraints, crustal anatexis in the kyanite stability field in Kali Gandaki valley, and in general in central and eastern Nepal, was ascribed to the underthrusting of the GHS beneath THS following continental collision (Carosi et al. 2015).

\section{Nanogranitoid inclusions}

The investigated garnet is $10 \mathrm{~mm}$ in diameter and contains hundreds of nanogranitoid inclusions showing a systematic distribution in an annulus located in an intermediate position between core and rim (Fig. 3a, b). Nanogranitoids are 10-20 $\mu \mathrm{m}$ in size, often show an irregular shape and coexist with tiny single mineral inclusions of ilmenite, rutile, apatite, zircon and monazite (Fig. 3c-f). These minerals also appear within melt inclusions (Fig. 3f) and represent accidental trapped phases, as suggested by their relative large size compared with the size of the inclusions, by their low solubility in crustal melts and by the presence of indentations within the inclusion walls (e.g., Cesare and Maineri 1999; Barich et al. 2014). Kyanite is not present as mineral inclusions within the investigated garnet, as already observed for other garnet porphyroblasts occurring in Ky-bearing migmatites from this area (Carosi et al. 2015). Cryptocrystalline aggregates of quartz + plagioclase + muscovite + chlorite \pm biotite commonly constitute nanogranitoids (Fig. 3c-f; see also Carosi et al. 2015), suggesting the former presence of a Si- and Al-rich melt. Experimental re-homogenization 
via piston cylinder apparatus at $800{ }^{\circ} \mathrm{C}$ (see details in Bartoli et al. 2013b) has confirmed the granitoid and peraluminous composition of the trapped melt $\left(\mathrm{SiO}_{2}>65 \mathrm{wt} \%, \mathrm{FeO} \approx 2-3 \mathrm{wt} \%\right.$, $\mathrm{CaO} \approx 1-4 \mathrm{wt} \%, \mathrm{Na}_{2} \mathrm{O} \approx 1-4 \mathrm{wt} \%, \mathrm{~K}_{2} \mathrm{O} \approx 0.3-2, \mathrm{P}_{2} \mathrm{O}_{5} \approx 0.2 \mathrm{wt} \%$ ASI $\geq 1.3$; Carosi et al. 2015;

Cesare et al. 2015).

\section{Analytical methods}

108 Trace elements in natural (experimentally untreated) and unexposed inclusions beneath garnet surface (Table 1) have been analyzed at the Department of Earth Sciences, ETH Zürich by laser ablation inductively coupled plasma mass spectrometry (LA-ICPMS) using a 111 GeoLas system for ablation coupled to an Element XR (Thermo Fisher, Germany). The glass 112 NIST SRM 610 was employed as external standard. The acquired time-resolved signals were 113 processed using the software SILLS (Guillong et al. 2008). Owing to the small size of 114 nanogranitoids, also part of the host garnet has been ablated along with target inclusions. 115 Therefore, the deconvolution of the resulting mixed garnet-glass signal was applied following 116 the procedure of Halter et al. (2002). The $\mathrm{Na}_{2} \mathrm{O}$ and $\mathrm{FeO}$ contents determined by EMP were 117 used as reference standards for inclusion and garnet, respectively. For elements enriched in 118 the inclusion, the concentrations is accurate within 20 to $40 \%$. Elements which are strongly 119 compatible in the host garnet (HREE, Y) are normally not detectable in the inclusions due to 120 the dominance of the host signal and were not collected. Gd, V, Zn and Sc show substantially 121 higher contents in the host garnet than in nanogranitoids (Table 1). Therefore, the amount of 122 these elements cannot be reliably estimated in the inclusions. Some inclusions show 123 anomalous very high concentrations of $\mathrm{Zr}$, Th, U, Hf and $\mathrm{Nb}$, suggesting the occurrence of accidental trapped phases (e.g., zircon, monazite, rutile and ilmenite). For these inclusions, only the content of $\mathrm{Li}, \mathrm{B}, \mathrm{Rb}, \mathrm{Sr}, \mathrm{Ba}$ was reported in Table 1 and discussed in the text. The $\mathrm{H}_{2} \mathrm{O}$ measurements of re-homogenized melt (i.e., glassy) inclusions (Table 2) were 
performed using the Cameca Nano Secondary Ion Mass Spectrometry 50 (NanoSIMS)

installed at Muséum National d'Histoire Naturelle (Paris). Polished experimental capsules

with glassy inclusions exposed on the garnet surface and standard glasses were mounted in indium (Aubaud et al. 2007). Inclusions were identified by collecting secondary ion images of $\mathrm{Si}, \mathrm{Al}, \mathrm{K}$ and $\mathrm{Fe}$. For each analysis location, a pre-sputtering step on a $3 \times 3 \mu \mathrm{m}^{2}$ surface area was firstly done for 2 minutes with a 360 pA primary $\mathrm{Cs}^{+}$beam to remove the gold coating, surface contamination and to reach a steady state sputtering regime (Thomen et al. 2014). Then a primary beam of $60 \mathrm{pA}$ was used for data acquisition. Data were acquired by rastering a $3 \times 3 \mu \mathrm{m}^{2}$ surface area and collecting ions only from the inner $1 \mathrm{x} 1 \mu \mathrm{m}^{2}$ (using the beam blanking mode) to reduce surface and redeposition contamination. In order to compensate charging effects, the electron gun was used while pre-sputtering and collecting time. Each analysis is a stack of 200 cycles, a cycle being $1.024 \mathrm{~s}$ long. ${ }^{16} \mathrm{OH}^{-}$(used as a proxy 139 for $\left.\mathrm{H}_{2} \mathrm{O}\right),{ }^{28} \mathrm{Si}^{-},{ }^{39} \mathrm{~K}^{16} \mathrm{O}^{-}$and ${ }^{56} \mathrm{Fe}^{16} \mathrm{O}^{-}$were recorded simultaneously in multicollection mode. $140 \mathrm{We}$ checked that ${ }^{16} \mathrm{OH}^{-28} \mathrm{Si}^{-}$ratio was stable during analyses. Secondary ions were collected 141 by electron multipliers with a dead time of $44 \mathrm{~ns}$. Mass resolution was set to 8000 , enough to 142 resolve isobaric interference on ${ }^{16} \mathrm{OH}^{-}$. For NanoSIMS calibration we used granitic glasses 143 showing different $\mathrm{H}_{2} \mathrm{O}$ contents (for details on calibration procedure and correction curve see 144 Bartoli et al. 2014). Data corrections, using the aforementioned calibration, and error 145 calculations were performed using the R program. Errors combine counting statistic and 146 uncertainty of the calibration curve. However, the errors reported in Table 2 are dominated 147 by the uncertainty of the calibration curve, which corresponds to prediction interval at $68 \%$. 148 During the session, the vacuum in the analysis chamber remained between 2.5 and $5 \times 10^{-10}$ 149 Torr. 


\section{Results}

Melt inclusions show highly variable concentrations of typical incompatible elements such as Li (40-400 ppm), B (200-3400 ppm), Rb (40-400 ppm), Sr (5-100) and Ba (30-900 ppm) (Table 1). The contents of elements typically controlled by the dissolution of accessory minerals are very low $(\mathrm{Zr}=3-8 \mathrm{ppm} ; \mathrm{Th}=0.1-1.2 \mathrm{ppm} ; \mathrm{LREE}=4-11 \mathrm{ppm}) . \mathrm{U}$ ranges from 1 to $8 \mathrm{ppm}$. The $\mathrm{Nb} / \mathrm{Ta}$ and $\mathrm{U} / \mathrm{Th}$ ratios are $3-15$ and 3-21, respectively. Nanogranitoids also contain appreciable amounts of Sc (3-76 ppm), V (0.4-20 ppm) and Zn (14-92 ppm), though these concentrations might be affected by contamination from the host (see above and Fig. 5a). When compared with the composition of the upper continental crust, nanogranitoids from Kali Gandaki are enriched in $\mathrm{Pb}, \mathrm{Li}$ and $\mathrm{B}$, and depleted in $\mathrm{Ba}$, Th, $\mathrm{Nb}$, LREE, MREE, $\mathrm{Sr}, \mathrm{Zr}$ and $\mathrm{Hf}$ (Fig. 4a). On the other hand, $\mathrm{Rb}, \mathrm{U}$ and Ta show variable degrees of enrichment and depletion. In the chondrite-normalized diagram, melt inclusions show weak to moderate positive Eu anomalies $\left(\mathrm{Eu} / \mathrm{Eu}^{*}=1.2-3.3\right)(\mathrm{Fig} .4 \mathrm{~b})$.

The $\mathrm{H}_{2} \mathrm{O}$ concentrations of the re-homogenized nanogranitoids determined by NanoSIMS span a relatively wide range of values from 6.5 to $10.5 \mathrm{wt} \%$, with one single value up to $14.4 \mathrm{wt} \%$ (mean value of $8.9 \pm 1.8 \mathrm{wt} \%$; Fig. 5 and Table 2). Melt inclusions were too small to perform replicated analyses within a single inclusion. However, the distribution of $\mathrm{H}_{2} \mathrm{O}$ is expected to be quite homogeneous in glassy inclusions obtained from remelting experiments (Bartoli et al. 2014; Acosta-Vigil et al. 2016). $\mathrm{H}_{2} \mathrm{O}$ estimated by

171 difference of electron microprobe totals from $100 \%$ yielded similar mean content $(9.6 \pm 1.4$ 172 wt\%) compared to the NanoSIMS mean data (Fig. 5).

Figure 6 shows zircon and monazite saturation temperatures $\left(\mathrm{T}_{\mathrm{Zrn}}\right.$ and $\mathrm{T}_{\mathrm{Mnz}}$, respectively) for investigated melt inclusions, calculated following methods proposed by Watson and Harrison (1984), Montel (1993) and Stepanov et al. (2012). $\mathrm{T}_{\mathrm{Zrn}}$ and $\mathrm{T}_{\mathrm{Mnz}}$ were calculated from nanogranitoids not containing accidental trapped minerals; we carefully 
avoided considering any data coming from analyses of nanogranitoids containing trapped

mineral inclusions such zircon or monazite (see above). $\mathrm{T}_{\text {Zrn }}$ values vary from 541 to $594{ }^{\circ} \mathrm{C}$.

The two different calibrations for the $\mathrm{T}_{\mathrm{Mnz}}$ thermometer provide different temperature ranges such as 544-650 ${ }^{\circ} \mathrm{C}$ (Montel 1993) and $412-533{ }^{\circ} \mathrm{C}$ (Stepanov et al. 2012).

\section{Phase equilibria modeling}

183 Migmatites from Kali Gandaki valley have been already investigated by means of phase 184 equilibria modeling (Iaccarino et al. 2015). In this contribution this approach was instead 185 applied considering only the average bulk composition of remelted nanogranitoids to

compare the predicted subsolidus mineral assemblages with those observed in the crystallized melt inclusions. The average $\mathrm{H}_{2} \mathrm{O}$ content was estimated by EMP-difference and is consistent with the NanoSIMS values (Fig. 5). Calculations were performed in the $\mathrm{Na}_{2} \mathrm{O}-\mathrm{CaO}-\mathrm{K}_{2} \mathrm{O}-$ $\mathrm{FeO}-\mathrm{MgO}-\mathrm{Al}_{2} \mathrm{O}_{3}-\mathrm{SiO}_{2}-\mathrm{H}_{2} \mathrm{O}$ (NCKFMASH) chemical system, using Perple_x software version 6.8.3. Considering the pitfalls and uncertainties related to phase equilibria approach (White et al. 2011; Bartoli et al. 2013c, 2016b; Forshaw et al. 2019) two $P-T$ sections were calculated for the same bulk composition, one using the internally consistent dataset hp04ver (Holland and Powell 2003) and the older activity-composition (a-x) models, and another calculated using dataset hp11ver (Holland and Powell 2011) and the re-parameterized a-X models. The following $\mathrm{a}-\mathrm{x}$ relations were selected. For hp11ver: melt, garnet, chlorite, orthopyroxene, muscovite, biotite and cordierite from White et al. (2014), ilmenite from White et al. (2000), plagioclase and K-feldspar from Holland \& Powell (2003). For hp04ver: melt from White et al. (2007), garnet, orthopyroxene and chlorite from Holland and Powell (1998), biotite from Tajčmanová et al. (2009), white mica from Coggon and Holland (2002), plagioclase from Newton et al. (1980) and K-feldspar from Thompson and Hovis (1979). An ideal model was used for cordierite and ilmenite. In all calculations pure phases included 
quartz, rutile, kyanite, sillimanite, andalusite and aqueous fluid.

The overall topology of the two $P-T$ sections appears somewhat different, but there are not important variations in terms of phase assemblages (Fig. 7). Modeling of the bulk composition for the investigated nanogranitoids shows the appearance of melt at $\mathrm{T}>680-690$ ${ }^{\circ} \mathrm{C}$ (Fig. 7). The subsolidus field is occupied by variable mineral assemblages which are mainly characterized by the presence of chlorite, biotite, muscovite, paragonite, garnet, plagioclase and quartz. At $<500{ }^{\circ} \mathrm{C}$ and $<0.4 \mathrm{GPa}$, the predicted stable mineral assemblages are quartz + plagioclase + muscovite + chlorite + biotite and quartz + plagioclase + muscovite + chlorite (Fig. 7). These assemblages resemble those observed in many nanogranitoid inclusions (see above). Some pores observed during SEM analysis (Fig. 3) likely reflect the former presence of volatiles (in particular $\mathrm{H}_{2} \mathrm{O}$ ) in excess to the amounts used by phyllosilicates and therefore exsolved during melt crystallization (see Bartoli et al. 2013a), in agreement with free $\mathrm{H}_{2} \mathrm{O}$ predicted by the model at subsolidus conditions (Fig. 7). In addition, the model indicates that chlorite is likely to be a phase formed in the subsolidus during cooling, whose formation did not involve infiltration of external fluids (i.e., the presence of chlorite in nanogranitoids does not imply that melt inclusions have been modify by late stage fluid alteration). This finding is also consistent with the coexistence of chlorite and unaltered biotite in nanogranitoids from Ivrea Zone (Carvalho et al., 2018).

\section{Discussion}

222 Nanogranitoids represent primary prograde Eohimalayan crustal melts

223 Their microstructural distribution, together with the experimental re-homogenization, major and trace element compositions and $\mathrm{H}_{2} \mathrm{O}$ contents, and results from phase equilibria modeling 225 (Carosi et al. 2015 and this work), confirm that these polycrystalline inclusions represent 226 former primary melt droplets that have crystallized into a cryptocrystalline aggregate; that is, 
they are nanogranitoids (Cesare et al. 2015; Bartoli et al. 2016a). Their systematic

distribution in an annulus around the garnet core points to a primary origin (Roedder 1979), implying that they were trapped by garnet during its growth. Therefore, the portion of garnet containing melt inclusions certainly formed in the presence of an anatectic melt during incongruent melting (i.e., this portion has certainly a peritectic origin: Cesare et al. 2015).

This is consistent with the increase of garnet mode (5 to 9 vol\%; Iaccarino et al. 2015) predicted by the modeling at the temperature of melting (Fig. 2b). The formation of peritectic garnet at $\leq 700{ }^{\circ} \mathrm{C}$ might appear problematic, but it was already documented in Ronda metatexites (S Spain), where it was interpreted as the consequence of a continuous melting reaction consuming biotite (Bartoli et al. 2013c). Also, geochemical signatures typical of muscovite melting were found in melt inclusions hosted in peritectic garnet from El Hoyazo anatectic enclaves (SE Spain), indicating that this peritectic mineral likely grew (and trapped melt droplets) through melting reactions consuming Fe-bearing muscovite at around 700-750 ${ }^{\circ} \mathrm{C}$ (Acosta-Vigil et al. 2010).

The investigated garnet has been collected at the base of a rock wall made of Kybearing, partially- melted gneiss. Rocks from this outcrop have been intensively studied in the recent years. On the basis of thermodynamic modeling, peritectic garnet likely grew in the presence of a melt phase from 650 to $720^{\circ} \mathrm{C}$, at 1.0-1.1 GPa (Fig. 2b; Iaccarino et al. 2015). In situ $\mathrm{U}-\mathrm{Th}-\mathrm{Pb}$ dating of monazite grains from rock matrix and included in melt inclusion-bearing garnets indicates the beginning of anatexis at c. 41-36 Ma (Fig. 2a; see also Carosi et al. 2015). Near peak-pressure melting has been dated at c. 36-28 Ma by Iaccarino et al., (2015). These geochronological constraints are in agreement with the age of c. $35 \mathrm{Ma}$ obtained by $\mathrm{U}-\mathrm{Pb}$ monazite and zircon dating of a Ky-bearing leucosome collected close to Taglung, 10-12 km from the Titar village (Godin et al. 2001). Considering their primary origin and the geochronological constraints reported above, 
it is reasonable to interpret that the investigated nanogranitoids reflect primary anatectic melts produced during the Eocene-Early Oligocene (Eohimalayan) prograde metamorphism associated to crustal thickening during the early stages of the India-Asia collision.

\section{Conditions and mechanisms of Eohimalayan anatexis in Kali Gandaki}

Most re-homogenized nanogranitoids from Kali Gandaki valley are granodiorites, tonalites and trondhjemites, and minor granites, showing low $\mathrm{K}_{2} \mathrm{O}$ contents $(<2.5 \mathrm{wt} \%)$, moderate to very high $\mathrm{Na}_{2} \mathrm{O} / \mathrm{K}_{2} \mathrm{O}$ ratio (1.1-14.1) and $\mathrm{CaO}$ up to 4 wt\% (Carosi et al., 2015; Bartoli et al., 2016a; Fig. 8). Notably, leucosomes in Kali Gandaki gneisses exhibit a tonalitic composition (Iaccarino et al. 2015). These peculiar compositions resemble those of experimental melts produced during $\mathrm{H}_{2} \mathrm{O}$-present melting of metasedimentary rocks (Fig. 8). For instance, Patiño Douce and Harris (1998) experimentally remelted two GHS schists from the hanging wall of the Main Central Thrust. Melts produced by dehydration melting of mica at $>750{ }^{\circ} \mathrm{C}(0.6-1.0 \mathrm{GPa})$ are granitic in compositions $\left(\mathrm{Na}_{2} \mathrm{O} / \mathrm{K}_{2} \mathrm{O}=0.7-0.9\right.$, one value up to 1.4). Instead, near-solidus melts formed at $<750{ }^{\circ} \mathrm{C}$ by $\mathrm{H}_{2} \mathrm{O}$-present melting of muscovite correspond to trondhjemites $\left(\mathrm{Na}_{2} \mathrm{O} / \mathrm{K}_{2} \mathrm{O}=1.4-3.9\right.$, one value of 0.9$)$. The $\mathrm{Na}_{2} \mathrm{O} / \mathrm{K}_{2} \mathrm{O}>1$ of melt has been ascribed to the decreasing temperature of quartz + plagioclase solidus with increasing $\mathrm{H}_{2} \mathrm{O}$ amount (Patiño Douce and Harris 1998; García-Casco et al. 2003). The weak to moderate positive Eu anomaly of Kali Gandaki nanogranitoids (Fig. 4b) would support the role of plagioclase in melting reaction (Gao et al. 2017). Therefore, based on the major element compositions of rehomogenized nanogranitoids, the presence of an aqueous fluid phase during the associated anatexis could be proposed.

The peculiar Na-rich composition of Kali Gandaki nanogranitoids with respect to classic granitic s.s. anatectic melts cannot be the result of melt-garnet interaction during experimental remelting at temperature $\left(800{ }^{\circ} \mathrm{C}\right)$ higher than that of entrapment $\left(650-720{ }^{\circ} \mathrm{C}\right)$, 
because the host mineral is virtually Na-free. Rather, this discrepancy is likely to be related to

278

4

5279

6

kinetics (see below).

Rehomogenized nanogranitoids have high $\mathrm{H}_{2} \mathrm{O}$ concentrations (6.5-10.5, one value up to $14.4 \mathrm{wt} \%$; Fig. 5). This range approximates the expected minimum and maximum $\mathrm{H}_{2} \mathrm{O}$ contents for anatectic melts produced at these P-T conditions $(\approx 6.5-15 \mathrm{wt} \%$; Holtz et al., 2001). The $\mathrm{H}_{2} \mathrm{O}$ content approaching the maximum solubility value ( $\approx 15 \mathrm{wt} . \%$ at $1.1 \mathrm{GPa}$ ) was found in a single nanogranitoid inclusion and it would be consistent with partial melting under fluid-present conditions at the $\mathrm{H}_{2} \mathrm{O}$-saturated solidus. The lower $\mathrm{H}_{2} \mathrm{O}$ concentrations may reflect different processes. 1) Weinberg and Hasalová (2015b) argue that in the case of a rock-buffered system (i.e., a system characterized by a high rock/fluid ratio) the $\mathrm{H}_{2} \mathrm{O}$-fluxed melting would produce $\mathrm{H}_{2} \mathrm{O}$-undersaturated melts and that the $\mathrm{H}_{2} \mathrm{O}$ contents would range between the minimum and maximum values. 2) Alternatively, different buffering assemblages at the micro-scale may be responsible for variable melt $\mathrm{H}_{2} \mathrm{O}$ content. Bartoli et al. (2014) documented that melt inclusions trapped in different garnet crystals in Ronda migmatites (Spain) showed variable $\mathrm{H}_{2} \mathrm{O}$ content and interpreted these heterogeneities as the result of melt formation under conditions of "mosaic equilibrium" affecting the activity of $\mathrm{H}_{2} \mathrm{O}$ in the coexisting fluid phase and/or the solid assemblages. This explanation seems to be highly improbable for Kali Gandaki sample where the distance among analyzed nanogranitoids is in the order of a few hundreds of $\mu \mathrm{m}$. 3) The loss of $\mathrm{H}_{2} \mathrm{O}$ after melt inclusion entrapment and/or during remelting experiments cannot be excluded a priori, considering the presence of cracks in some inclusions (Fig. 3c). However, a systematic loss of $\mathrm{H}_{2} \mathrm{O}$ from nanogranitoids during subsolidus retrograde history is expected to result in a larger variability of the melt $\mathrm{H}_{2} \mathrm{O}$ contents, with compositions approaching dry values. This is not the case here, where the majority of melt $\mathrm{H}_{2} \mathrm{O}$ contents define a relatively narrow range, never below $6.5 \mathrm{wt} \%$ (Fig. 5). 
One could argue that $\mathrm{H}_{2} \mathrm{O}$ loss after melt inclusion entrapment could partly explain

the discrepancy between the trapping temperature and the temperature at which

nanogranitoids were experimentally remelted $\left(800^{\circ} \mathrm{C}\right)$. However, again, this discrepancy

may be explained without taking into account the loss of $\mathrm{H}_{2} \mathrm{O}$. Indeed, higher remelting temperatures could be needed because melting kinetics play a fundamental role during reheating experiments. Smaller inclusions usually remelt more rapidly than larger ones (Thomas and Klemm 1997) and nanogranitoids from Kali Gandaki show larger size than melt inclusions for which a run duration of $24 \mathrm{~h}$ was tested (Bartoli et al., 2013c and discussion therein). Therefore, a process of $\mathrm{H}_{2} \mathrm{O}$ loss affecting the majority of analyzed inclusions does not seem to be supported by convincing evidence.

To summarize, the occurrence of near $\mathrm{H}_{2} \mathrm{O}$-saturated melts would support a $\mathrm{H}_{2} \mathrm{O}$ present melting scenario, confirming the inferences based on major element compositions of nanogranitoids and temperature estimates of Kali Gandaki migmatites (see above). The observed $\mathrm{H}_{2} \mathrm{O}$ variability, which is likely to be primary and ranges between the expected minimum and maximum values, would suggest the existence of a $\mathrm{H}_{2} \mathrm{O}$-present, rock-buffered system during Eohimalayan anatexis. These observations are consistent with anatexis and melt formation in the proximity of the $\mathrm{H}_{2} \mathrm{O}$-saturated solidus (Fig. 2).

$\mathrm{T}_{\mathrm{Zrn}}$ and $\mathrm{T}_{\mathrm{Mnz}}$ are $\approx 100-250{ }^{\circ} \mathrm{C}$ lower than suprasolidus temperatures obtained for migmatites collected in the same area (Fig. 6). $\mathrm{T}_{\mathrm{Znn}}$ and $\mathrm{T}_{\mathrm{Mnz}}$ values are also notably lower than the minimum temperature at which crustal protoliths melt in the presence of an aqueous fluid $\left(\approx 650^{\circ} \mathrm{C}\right)$. Migmatites from Kali Gandaki valley contain abundant grains of zircon and monazite occurring in matrix as well as in garnet, kyanite, biotite and quartz (Carosi et al. 2015; Iaccarino et al. 2015). In addition, these accessory minerals are present as accidentally trapped phases within some nanogranitoids (Fig. 3d, f). One, therefore, could assume that melt pockets were likely in contact with zircon and monazite during the early stages of 
melting. Because zircon and monazite are expected to break down and dissolve at

suprasolidus conditions during prograde metamorphism to maintain saturation of the melt (Yakymchuk and Brown 2014; Yakymchuk 2017), the undersaturated composition of melt inclusions with respect to the accessory minerals would suggest a limited time of interaction between zircon/monazite and anatectic melt. On the other hand, the amount of melt was likely low (around the percolation threshold; Fig. 2) and, therefore, the lack of contact with accessory phases cannot be excluded. In any case, the very low $\mathrm{T}_{\mathrm{Zrn}}$ and $\mathrm{T}_{\mathrm{Mnz}}$ values have to be ascribed to the lack of equilibration between melt pockets and accessory minerals present in the rock. Some degrees of disequilibrium involving accessory minerals and melt inclusions in anatectic rocks have been already documented during the entrapment of low-temperature $\left(<750{ }^{\circ} \mathrm{C}\right)$ melt droplets in El Hoyazo metapelitic enclaves (Acosta-Vigil et al. 2010). In that case, a much smaller difference of $25-50{ }^{\circ} \mathrm{C}$ between calculated and expected temperatures has been reported (see discussion in Acosta-Vigil et al. 2012).

To date, the most complete dataset of trace element compositions of melt inclusions from metapelitic anatectic rocks is that presented by Acosta-Vigil et al. (2010, 2012). In residual anatectic enclaves within peraluminous dacites of the Neogene Volcanic Province (NVP) of SE Spain, a systematic evolution of trace element content of anatectic melt (recorded as melt inclusions in several minerals and as matrix glass) is observed. Combining microstructural and geochemical data, these authors interpreted that concentrations in melt of $\mathrm{Li}, \mathrm{Cs}$ and $\mathrm{B}$ decrease whereas those of $\mathrm{Zr}$, Th, REE, V, Cr, Co, Zn increase with increasing melting temperature, due to the consumption of muscovite (main carrier of $\mathrm{Li}, \mathrm{B}$ and $\mathrm{Cs}$ ) at low temperature and biotite (main reservoir of $\mathrm{Rb}$ ) and accessory phases (LREE, $\mathrm{Zr}$, Hf, U, 349 Th) at higher temperature (Acosta-Vigil et al. 2010). These authors interpreted the melt 350 inclusions in plagioclase and garnet to represent crustal melts formed by the $\mathrm{H}_{2} \mathrm{O}$-present to $351 \mathrm{H}_{2} \mathrm{O}$-absent muscovite melting reactions, whereas the matrix glass formed by biotite fluid- 
absent melting (see also Acosta-Vigil et al. 2017).

The majority of investigated nanogranitoids from Kali Gandaki valley show higher B content, similar Li concentration and $\mathrm{Rb} / \mathrm{Sr}$ ratio, and lower $\mathrm{Ba}, \mathrm{Ce}, \mathrm{Th}, \mathrm{Zr}$, Hf and $\mathrm{Rb} / \mathrm{B}$ values with respect to NVP melts produced at $\leq 750{ }^{\circ} \mathrm{C}$ (Fig. 9). The U/Th ratio is variable, from values approaching those observed in El Hoyazo low-temperature melts up to much greater contents (> 10; Fig. 9g), suggesting that Kali Gandaki nanogranitoids could reflect the composition of the first melt produced. All these compositional features are consistent with i) melting at low temperature and ii) the undersaturation of melt with respect to the accessory minerals (see above). Two melt inclusions from the investigated garnet display very high $\mathrm{Ba}$ amount (> 600 ppm; Fig. 9c). The high B contents (Fig. 9a, b) may point to the presence and dissolution of tourmaline during the melt-producing reaction. Indeed, this mineral is a common accessory phase in Ky-bearing gneisses from this area (Iaccarino et al. 2015). Wolf and London (1997) experimentally demonstrated that at the onset of crustal melting tourmaline breaks down incongruently to assemblages containing $\mathrm{Al}-, \mathrm{Fe}-$ and/or Mg-bearing solid phases (i.e., garnet, biotite, sillimanite) and a B-enriched melt. Alternatively, the infiltration of B-rich fluids into the anatectic zone and formation of B-enriched melts cannot be ruled out (Acosta et al. 2001; and references therein) and it would be consistent with a melting scenario characterized by the presence of an aqueous fluid (see above).

Acosta-Vigil et al. (2012) modeled REE abundance in crustal melts of El Hoyazo

371 considering different scenarios (e.g., disequilibrium melting of feldspars, equilibrium

372 dissolution of accessory phases and equilibrium with major and accessory minerals).

Similarly, Prince et al. (2001) calculated REE profiles of crustal melts derived from GHS metapelites assuming that REE abundances are controlled by accessory phase dissolution and by disequilibrium melting of plagioclase. Collectively these calculations indicate that REEpoor melts with a strong positive Eu anomaly can be due to the disequilibrium melting of 
feldspars, whereas dissolution of accessory phases results in higher REE contents and negative Eu anomalies (Fig. 10). The REE pattern and positive Eu anomalies of Kali Gandaki nanogranioids resemble those of El Hoyazo melt inclusions hosted in garnet and models based on the dissolution of feldpars, and differ significantly from models associated with the dissolution of accessory minerals (Fig. 10). Therefore, it follows that the latter process is not likely responsible for the REE abundances of nanogranitoids. Also, the extremely variable, LREE concentrations in melt suggest the lack of equilibration between melt and residue.

\section{Eohimalayan anatexis and granitoid formation}

Kyanite-bearing migmatitic gneisses of the lower GHS in the Kali Gandaki valley underwent low temperature (up to $720{ }^{\circ} \mathrm{C}$ ) Eocene to Early Oligocene anatexis, with the formation of low amounts of melt $(\approx 7.5$ vol.\%; Fig. 2 b) at peak conditions (Carosi et al. 2015 ; Iaccarino et al. 2015). However, similar rocks, which represent significant portions of the metamorphic core of the Himalayas, experienced higher temperatures and/or higher melting degrees in other localities of GHS, between Eocene and Late Oligocene.

For example, the Ky-bearing migmatites in the Main Central Thrust Zone (Arun valley, eastern Nepal Himalaya) reached peak conditions at $820{ }^{\circ} \mathrm{C}$ and $1.3 \mathrm{GPa}$, during Early Oligocene ( $\approx 31 \mathrm{Ma}$ ), producing $\approx 15$ vol.\% melt (Groppo et al. 2010). Guilmette et al. (2011) reported peak conditions of $820^{\circ} \mathrm{C}$ and $>1.4 \mathrm{GPa}$ for Ky-bearing anatectic paragneisses from the Namche Barwa (Eastern Himalayan Syntaxis). Here partial melting is considered to have generated 20-23 vol.\% total melt. The HP metamorphism was dated at 37-32 Ma (Zhang et al. 2010). Zhang et al. (2015) documented melting of pelitic granulites from the same area 399 (Namche Barwa Complex) at peak conditions of $840-880^{\circ} \mathrm{C}$ and $1.3-1.6 \mathrm{GPa}$; anatexis of 400 these rocks produced up to $\approx 30$ vol. $\%$ melt from c. 40 to 30 Ma. Here metagreywackes 401 reached peak consitions of $820-845^{\circ} \mathrm{C}$ and $1.5-1.6 \mathrm{GPa}$ (Tian et al. 2016). Palin et al. (2014) 
dated the melting at $\approx 700{ }^{\circ} \mathrm{C}$ and $\approx 1.0 \mathrm{GPa}$ in the northwestern flank of the Eastern

Himalayan Syntaxis between c. 44 and 33 Ma. Leucosomes in Ky-bearing migmatites

comprise up to $20 \%$ of the outcrop and formed as a result of Kfs-absent, fluid present melting reactions. In the Kharta Area (Southern Tibet) metasedimentary migmatites experienced anatectic conditions of $750-800{ }^{\circ} \mathrm{C}$ and $1.4 \mathrm{GPa}$, at $\approx 33 \mathrm{Ma}$ (Liu et al. 2007). Phase equilibria modeling demonstrated that Barun gneisses (Eastern Nepal) reached peak conditions of 800$850{ }^{\circ} \mathrm{C}$ in the kyanite field, with the formation of 15-20 vol.\% melt (Groppo et al. 2012).

Melting at the bottom of the GHS (e.g., Barun gneisses) was dated at 33-28 Ma (Carosi et al. 2015 and references therein).

Considering their low melting temperature and degree, Kali Gandaki anatectic gneisses probably did not act as source region of voluminous anatectic melts. However, from the above, it is clear that Ky-bearing migmatites have played an important role during Eohimalayan anatexis. As a matter of fact, melting of metasedimentary lithologies from GHS is considered to have contributed to the granitoid magmatism occurred during crustal thickening at variable temperatures and under variable fluid regimes (Prince et al. 2001; Zeng et al. 2009; 2011; Aikman et al. 2012). Therefore, nanogranitoids from Kali Gandaki gneisses may provide us with a snapshot of anatectic melts whose extraction from similar lithologies and emplacement at shallower levels have resulted in the formation of Eohimalayan granitoids.

Granitic to trondhjemitic bodies from the upper GHS of Garhwal Himalaya are considered to be derived from $\mathrm{H}_{2} \mathrm{O}$-present melting of Ky-bearing GHS metasedimentary rocks at $650{ }^{\circ} \mathrm{C}$ during Eohimalayan prograde metamorphism $(39 \pm 3 \mathrm{Ma})$ (Prince et al. 2001). These Eohimalayan granitoids, which differ from the classic Miocene leucogranites, share some key features with the Kali Gandaki melt inclusions, such as $\mathrm{Ca}$ - and $\mathrm{Na}-$ enrichment (up to 2.0 and $3.9 \mathrm{wt} \%$, respectively), very low melting temperatures and a 
positive Eu anomaly (Prince et al. 2001). In the haplogranitic Qtz-Ab-Or diagram the (3) 4

Garhwal rocks plot in the proximity of Kali Gandaki nanogranitoids and experimental glasses produced via $\mathrm{H}_{2} \mathrm{O}$-present melting (Fig. 8). Anatectic gneisses of Kali Gandaki valley may reasonably be considered the analog source rocks of Eohimalayan Garhwal granitoids. Active shear zones in this area could have facilitated the ingress of external fluids, enhancing the amount of melt produced (Prince et al. 2001). Instead, a large supply of external aqueous fluids did not occur in Kali Gandaki area where melting stopped at low degrees.

Granite compositions have been often interpreted in the light of "restite unmixing" model (Chappell et al. 1987), which states that the majority of granites represent mixtures between a minimum or near-minimum temperature melt and the restite (residuum), and that the compositional variability in granites reflects varying degrees of restite unmixing.

The $\mathrm{Ba}$ and $\mathrm{Sr}$ content of three Garhwal granites can be modeled as the variable mixture of a starting melt (represented by nanogranitoids) and a residuum composed of variable amounts of biotite, plagioclase and K-feldspar (Fig. 9d). One rock needs solely the addition of 5 vol\% K-feldspar. However, the same mixtures with a biotite-bearing residuum would result in $\mathrm{Rb} / \mathrm{Sr}$ ratios much higher $(\approx 12)$ than those measured $(<1$; Fig. 9c). The very high $\mathrm{Ba}$ content and very low $\mathrm{Rb} / \mathrm{Sr}$ of Garhwal rocks could, instead, be explained by addition of solely K-feldspar, up to 20 vol\% (Fig. 9c). These mismatches clearly indicate that entrapment of residual minerals does not explain the trace element concentrations controlled by major minerals. Although the addition of very tiny amounts of zircon and monazite could explain Ce, Th, $\mathrm{U}$ and $\mathrm{Zr}$ variability in Garhwal rocks (Fig. 9e, f), this is unlikely. Firstly, the entrainment of phases from the source region is not a selective process (Sawyer 2014).

449 Rather, the inheritance of accessory minerals should be coupled with that of major phases in 450 which they are usually included (micas and feldspars). Again, the mixing with a biotite-, 451 feldspar-bearing residuum is highly improbable (see above). Secondly, the higher Zr, Th and 
452 Ce contents are perfectly consistent with higher degrees of melting compared to those in Kali 453 Gandaki migmatites. Accessory phase dissolution and disequilibrium melting of plagioclase are considered to have shaped the LREE patterns and positive Eu anomaly, respectively, of Garhwal rocks (Fig. 10; Prince et al. 2001). This is mostly in agreement with the diverse La, Ce and Eu contents of Kali Gandaki nanogranitoids whose composition seems to be controlled by the dissolution of plagioclase and lack of equilibrium with accessory minerals (Fig. 10).

Prince et al. (2001) ascribed the very high Ba content of these rocks (> 600 ppm; Fig. 9c) to fluid transport of $\mathrm{Ba}$, which "is a well-documented phenomenon during crustal melting (Weinberg and Searle 1999)”. Surprisingly, Ba is highly variable in Kali Gandaki nanogranitoids, formed in a $\mathrm{H}_{2} \mathrm{O}$-present scenario (see above), with the highest contents resembling those observed in some Garhwal rocks (Fig. 9c).

Summarizing, the comparison between nanogranitoids and granites indicates i) that the restite unmixing process did not shape the composition of Garhwal rocks and that an aqueous fluid was involved in melting process, reinforcing the inferences of Prince et al. (2001), and ii) that Kali Gandaki melt inclusions are recording the very beginning of melting in a scenario that, in other GHS localities, has produced Eohimalayan granitoids.

\section{Conclusions}

1. Kali Gandaki nanogranitoids occur within peritectic garnet whose formation has been ascribed to the Eohimalayan prograde metamorphism at conditions of $650-720{ }^{\circ} \mathrm{C}$ and 1.0-1.1 GPa and has been dated at c. 41-36 Ma (see Carosi et al. 2015; Iaccarino et al. 2015).

2. During their crystallization, nanogranitoids developed a quartz + plagioclase + muscovite + chlorite \pm biotite assemblage 
3. Major element compositions and $\mathrm{H}_{2} \mathrm{O}$ contents of rehomogenized nanogranitoids suggest the presence of an aqueous fluid phase during melting, in agreement with the inferred melting conditions.

4. The low Zr, Th and LREE concentrations along with the very low zircon and monazite saturation temperatures indicate some degrees of disequilibrium between accessory minerals and coexisting melt.

5. Investigated nanogranitoids are incipient melts, which did not have time to equilibrate with their source rock.

6. Kali Gandaki nanogranitoids share some key features with Eohimalayan granitoids from Garhwal Himalaya (i.e., major elements, very low melting temperature, $\mathrm{Ba}$ enrichment). A comparative study supports previous inferences of Prince et al. (2001): Garhwal rocks likely represent pristine crustal melts formed under $\mathrm{H}_{2} \mathrm{O}$ present conditions, whose composition was not modified by entrainment of residuum.

Acknowledgments This research benefitted from funding from the Italian Ministry of 492 Education, University, Research (Progetto SIR RBSI14Y7PF), from Padova University 493 (Progetti per Giovani Studiosi 2013) and from Società Italiana di Mineralogia e Petrologia 494 (grant for a research stay abroad) to OB; from the CARIPARO (Cassa di Risparmio di 495 Padova e Rovigo) project MAKEARTH to BC. The National NanoSIMS facility at the 496 MNHN was established by funds from the CNRS, Région Ile de France, Ministère délégué à 497 l'Enseignement supérieur et à la Recherche, and the MNHN. Remi Duhamel is thanked for 498 his support during NanoSIMS analyses. 
FIGURE and TABLE CAPTIONS

501

502

6

7503

10

11

12505

13

14

15

16

17507

18

19

20

21

22509

23

24

25

26

27

28

29

Fig. 1 Geological sketch map of the Kali Gandaki valley (redrawn from Carosi et al. 2015)

Fig. 2 a) Representative hand specimen of the anatectic paragneisses. b) Phase equilibria modeling and P-T path of Ky-bearing gneisses from Kali Gandaki valley (redrawn from Iaccarino et al., 2015). Green rectangle: temperature range from the thermometer based on $\mathrm{Zr}$ content in rutile. C2015 and I2015: geochronological constraints from Carosi et al. (2015) and Iaccarino et al. (2015), respectively

510 Fig. 3 Melt inclusions in garnet from Kali Gandaki. a) plane-polarized photomicrograph of 511 the equatorial section of the investigated garnet. Dashed white lines define the annulus 512 containing nanogranitoid inclusions (redrawn after Cesare et al. 2015). b) plane-polarized 513 photomicrograph showing a cluster of polycrystalline inclusions. c-f) SEM-BSE images of 514 nanogranitoids. Red arrows: decrepitation cracks. Yellow arrows: micro- to nano-porosity. 515 Scale bar: $5 \mu \mathrm{m}$

517 Fig. 4 Trace element and REE composition of nanogranitoid inclusions (NG) and host garnet. 518 a) Values normalized to the average upper continental crust (UCC) composition (data from 519 Rudnick and Gao 2014). b) REE patterns. Values normalized to the chondrite C1 (Sun and 520 McDonough 1989)

522 Fig. $5 \mathrm{H}_{2} \mathrm{O}$ concentrations of nanogranitoid inclusions determined by NanoSIMS. The error 523 associated to these values is smaller than the symbol (see Table 2). White symbols: average 524 contents. The average $\mathrm{H}_{2} \mathrm{O}$ content estimated by EMP-difference is from Cesare et al. (2015). 
525 Horizontal bars are two standard deviations on average values. The number of analyses is

6
Fig. 6 Monazite and zircon saturation temperatures calculated for the investigated melt inclusions. Black dots: $\mathrm{T}_{\mathrm{Mnz}}$ calibration of Montel (1993). White dots: $\mathrm{T}_{\mathrm{Mnz}}$ calibration of Stepanov et al (2012). $\mathrm{T}_{\mathrm{Zn}}$ from Watson and Harrison (1984). Grey field: anatectic temperatures estimated for Kali Gandaki gneisses by Iaccarino et al. (2015)

Fig. 7 Comparative $\mathrm{P}-\mathrm{T}$ sections for nanogranitoid inclusions calculated in the NCKFMASH system with two internally consistent datasets: hp04ver for (a) and hp11ver for (b). The bulk composition $(\mathrm{mol} \%)$ used for calculation is indicated in the upper right inset and represents the average composition obtained by EMP. The average $\mathrm{H}_{2} \mathrm{O}$ content was estimated by EMPdifference and is consistent with the NanoSIMS values

Fig. 8 Qtz-Ab-Or diagram showing the normative compositions of Kali Gandaki nanogranitoids (square represents the average value). Compositions of experimental glasses (PDH98: Patiño Douce and Harris 1998; GC03: García-Casco et al. 2003) and Eohimalayan granites (P2001: Prince et al. 2001) are plotted for comparison

Fig. 9 Comparison among the trace element contents (ppm) of Kali Gandaki nanogranitoids, El Hoyazo melts and Eohimalayan granitoids. Ba and Sr content of melt inclusions in plagioclase were not reported because these elements are depleted being compatible with respect the host phase; Hf concentrations were not reported for inclusions in plagioclase in the original database (see Acosta-Vigil et al. 2012). Temperature estimates correspond to zircon and monazite saturation temperatures reported by Acosta-Vigil et al. (2010). Lines 
track the result of melt-residuum mixing models. Tick marks on the lines reflect increments

of the residuum. The average composition of nanogranitoids was considered as representative

of the starting melt composition, except for $\mathrm{Ba}-\mathrm{Rb} / \mathrm{Sr}$ and $\mathrm{Ba}-\mathrm{Sr}$ diagrams where the two $\mathrm{Ba}-$

rich melt inclusions were not considered for the average value. This assumption does not

change the inferences obtained from the geochemical modeling. Mineral compositions are

from Acosta-Vigil et al. (2010). See text for details

Fig. 10 Comparison of REE abundances of Kali Gandaki nanogranitoids, Garwhal granites and low-temperature anatectic melts modelled by Prince et al. (2001) [P2001] and AcostaVigil et al. (2012) [AAV2012]. See text for details.

Table 1 LA-ICP-MS analyses (ppm) of melt inclusions from Kali Gandaki garnet

Table $2 \mathrm{H}_{2} \mathrm{O}$ concentrations measured in nanogranitoids by NanoSIMS

\section{References}

Acosta A, Pereira MD, Shaw DM, London D (2001) Contrasting behaviour of B during crustal anatexis. Lithos 56:15-31

Acosta-Vigil A, Barich A, Bartoli O, Garrido C, Cesare B, Remusat L, Poli S, Raepsaet C (2016) The composition of nanogranitoids in migmatites overlying the Ronda peridotites (Betic Cordillera, S Spain): the anatectic history of a polymetamorphic basement. Contrib Mineral Pet 171:24

Acosta-Vigil A, Buick I, Cesare B, London D, Morgan GB VI (2012b) The extent of equilibration between melt and residuum during regional anatexis and its implications for differentiation of the continental crust: a study of partially melted metapelitic enclaves. $\mathbf{J}$ Petrol 53:1319-1356

Acosta-Vigil A, Buick I, Hermann J, Cesare B, Rubatto D, London D, Morgan GB VI (2010) Mechanisms of crustal anatexis: a geochemical study of partially melted metapelitic enclaves and host dacite, SE Spain. J Petrol 51:785-821

Acosta-Vigil A, London D, Morgan VI GB, Cesare B, Buick I, Hermann J, Bartoli O (2017) Primary crustal melt compositions: Insights into the controls, mechanisms and timing of generation from kinetics experiments and melt inclusions. Lithos 286-287:454-479

Aikman AB, Harrison TM, Hermann J (2012) The origin of Eo- and Neo-himalayan granitoids, Eastern Tibet. J Asian Earth Sc 58:143-157 
Aubaud C, Withers AC, Hirschmann MM, Guan Y, Leshin LA, Mackwell SJ, Bell DR (2007) Intercalibration of FTIR and SIMS for hydrogen measurements in glasses and nominally anhydrous minerals. Am Mineral 92:811-828

Barich A, Acosta-Vigil A, Garrido CJ, Cesare B, Tajc`manová L, Bartoli O (2014) Microstructures and petrology of melt inclusions in the anatectic sequence of Jubrique (Betic Cordillera, S Spain): implications for crustal anatexis. Lithos 206-207:303-320

Bartoli O, Acosta-Vigil A, Ferrero S, Cesare B (2016a) Granitoid magmas preserved as melt inclusions in high-grade metamorphic rock. Am Mineral 101:1543-1559

Bartoli O, Acosta-Vigil A, Tajčmanová L, Cesare B, Bodnar RJ (2016b) Using nanogranitoids and phase equilibria modeling to unravel anatexis in the crustal footwall of the Ronda peridotites (Betic Cordillera, S Spain). Lithos 256-257: 282-299

Bartoli O, Cesare B, Poli S, Acosta-Vigil A, Esposito R, Turina A, Bodnar RJ, Angel RJ, Hunter J (2013b) Nanogranite inclusions in migmatitic garnet: behavior during piston cylinder re-melting experiments. Geofluids 13:405-420

Bartoli O, Cesare B, Poli S, Bodnar RJ, Acosta-Vigil A, Frezzotti ML, Meli S (2013a) Recovering the composition of melt and the fluid regime at the onset of crustal anatexis and S-type granite formation. Geology 41:115-118

Bartoli O, Tajčmanová L, Cesare B, Acosta-Vigil A (2013c) Phase equilibria constraints on melting of stromatic migmatites from Ronda (S. Spain): insights on the formation of peritectic garnet. J Metamorphic Geol 31:775-789

Bartoli O, Cesare B, Remusat L, Acosta-Vigil A, Poli S (2014) The $\mathrm{H}_{2} \mathrm{O}$ content of granite embryos. Earth Planet Sci Lett 395:281-290

Brown RL, Nazarchuk JH (1993) Annapurna detachment fault in the Greater Himalaya of Central Nepal. Geol Soc London Sp Publ 74:461-473

Carosi R, Gemignani L, Godin L, Iaccarino S, Larson KP, Montomoli C, Rai SM (2014) A geological journey through the deepest gorge on Earth: the Kali Gandaki valley section, west-central Nepal. Journal of Virtual Explorer 47 (paper 7)

Carosi R, Montomoli C, Iaccarino S (2018) 20 years of geological mapping of the metamorphic core across Central and Eastern Himalayas. Earth-Science Rev 177:124-138

Carosi R, Montomoli C, Langone A, Turina A, Cesare B, Iaccarino S, Fascioli L, Visonà D, Ronchi A, Rai SM (2015) Eocene partial melting recorded in peritectic garnets from kyanite-gneiss, Greater Himalayan Sequence, central Nepal. Geol Soc London Sp Publ 412:111

Carvalho BB, Bartoli O, Ferri F, Cesare B, Ferrero F, Remusat L, Capizzi L, Poli S (2018) Anatexis and fluid regime of the deep continental crust: new clues from melt and fluid inclusions in metapelitic migmatites from Ivrea Zone (NW Italy). J Metamorphic Geol, DOI: $10.1111 /$ jmg. 12463

Carvalho BB, Sawyer EW, Janasi VA (2016) Crustal reworking in a shear zone: transformation of metagranite to migmatite. J Metamorphic Geol 34:237-264

Carvalho BB, Sawyer EW, Janasi VA (2017) Enhancing maficity of granitic magma during anatexis: entrainment of infertile mafic lithologies. J Petrol 58:1333-1362

Cesare B, Maineri C (1999) Fluid-present anatexis of metapelites at El Joyazo (SE Spain): constraints from Raman spectroscopy of graphite. Contrib Mineral Pet 135:41-52

Cesare B, Acosta-Vigil A, Bartoli O, Ferrero S (2015) What can we learn from melt inclusions in migmatites and granulites? Lithos 239:186-216

Chappell BW, White AJR, Wyborn D (1987) The importance of residual source material (Restite) in granite petrogenesis. J Petrol 28:1111-1138

Coggon R, Holland TJB (2002) Mixing properties of phengitic micas and revised garnetphengite thermobarometers. J Metamorphic Geol 20:683-696

Davidson C, Grujic DE, Hollister LS, Schmid SM (1997) Metamorphic reactions related to 
decompression and synkinematic intrusion of leucogranite, High Himalayan Crystallines, Bhutan. J Metamorphic Geol 15:593-612

Ferrero F, Angel (2018) Micropetrology: Are inclusions grains of truth? J Petrol 59:16711700

Forshaw JB, Waters DJ, Pattison DRM, Palin RM, Gopon PA (2019) Comparison of observed and thermodynamically predicted phase equilibria and mineral compositions in mafic granulites. J Metamorphic Geol 37:153-179

Gao Li-E, Zeng L, Asimow PD (2017) Contrasting geochemical signatures of fluid-absent versus fluid-fluxed melting of muscovite in metasedimentary sources: The Himalayan leucogranites. Geology 45:39-42

García-Casco A, Haissen F, Castro A, El-Hmidi H, Torres-Roldán RL, Millán G (2003) Synthesis of staurolite in melting experiments of a natural metapelite: consequences for the phase relations in low-temperature pelitic migmatites. J Petrol 44:1727-1757

Godin L (2003) Structural evolution of the Tethyan sedimentary sequence in the Annapurna area, central Nepal Himalaya. J As Earth Sc 22:307-328

Godin L, Parish RR, Brown L, Hodges KV (2001) Crustal thickening leading to exhumation of the Himalayan Metamorphic core of central Nepal: insight from U-Pb geochronology and ${ }^{40} \mathrm{Ar} /{ }^{39} \mathrm{Ar}$ thermochronology. Tectonics 20:729-747

Groppo C, Rolfo F, Indares A (2012) Partial melting in the Higher Himalayan Crystallines of Eastern Nepal: the effect of decompression and implications for the 'Channel Flow' model. J Petrol 53:1057-1088

Groppo C, Rubatto D, Rolfo F, Lombardo B (2010) Early Oligocene partial melting in Main Central Thrust Zone (Arun valley, eastern Nepal Himalaya). Lithos 118:287-301.

Guillong M, Meier DL, Allan MM, Heinrich CA, Yardley BWD (2008) SILLS: A MATLAB-based program for the reduction of laser ablation ICP-MS data of homogeneous materials and inclusions. Mineralogical Association of Canada Short Course 40, Vancouver, B.C., p. 328-333.

Guilmette C, Indares A, Hébert R (2011) High-pressure anatectic paragneisses from the Namche Barwa, Eastern Himalayan Syntaxis: textural evidence for partial melting, phase equilibria modeling and tectonic implications. Lithos 124:66-81

Halter WE, Pettke T, Heinrich CA, Rothen-Rutishauser B (2002) Major to trace element analysis of melt inclusions by laser-ablation ICP-MS: methods of quantification. Chem Geol 183:63-86

Harris N, Massey (1994) Decompression and anatexis of Himalayan metapelites. Tectonics 13:1537-1546

Harris N, Ayres M, Massey J (1995) Geochemistry of granitic melts produced during the incongruent melting of muscovite: implication for the extraction of Himalayan leucogranite magmas: J Geoph Res 100:15,767-15,777

Harrison TM (2006) Did the Himalayan crystallines extrude partially molten from beneath the Tibetan Plateau? In: Geological Constraints on Channel Flow and Ductile Extrusion as an Important Orogenic Process - Himalaya-Tibetan Plateau (eds Law, R.D., Searle, M.P. \& Godin, L.), Geological Society, London, Special Publication, 268:237-254

Hodges KV (2000) Tectonics of the Himalaya and southern Tibet from two perspectives. Geol Soc Am Bull 112:324-350

Hodges KV, Parrish RR, Searle MP (1996) Tectonic evolution of the central Annapurna Range, Nepalese Himalayas. Tectonics 15:1264-1291.

Holland TJB, Powell R (1998) An internally consistent thermodynamic data set for phases of petrological interest. J Metamorphic Geol 16:309-343

Holland TJB, Powell R (2003) Activity-composition relations for phases in petrological calculations: An asymmetric multicomponent formulation. Contrib Mineral Pet 145:492- 

thermodynamic dataset for phases of petrological interest, involving a new equation of state for solids. J Metamorphic Geol 29(3):333-383

Holtz F, Johannes W, Tamic N, Behrens H (2001) Maximum and minimum water contents of granitic melts generated in the crust: a reevaluation and implications. Lithos 56:1-14

Hu X, Garzanti E, Wang J, Huang W, An W, Webb A (2016) The timing of India-Asia collision onset - facts, theories, controversies. Earth-Sci Rev160: 264-299

Iaccarino S, Montomoli C, Carosi R, Massonne H-Jì, Langone A, Visonà D (2015) Pressuretemperature-time-deformation path of kyanite-bearing migmatitic paragneiss in the Kali Gandaki valley (Central Nepal): investigation of Late Eocene-Early Oligocene melting processes. Lithos 231:103-121

Iaccarino S, Montomoli C, Carosi R, Massonne H-Jì, Langone A, Visonà D (2017) Geology and tectono-metamorphic evolution of the Himalayan metamorphic core: insights from the Mugu Karnali transect, Western Nepal (Central Himalaya). J Metamorphic Geol 35:301325

Inger S, Harris NBW (1992) Tectonothermal evolution of the High Himalayan crystalline sequence, Langtang Valley, northern Nepal. J Metamorphic Geol 10:439-452

Kellett DA, Godin L (2009) Pre-Miocene deformation of the Himalayan superstructure, Hidden valley, central Nepal. J Geol Soc London 166:261-275

Kohn, M.J., 2014. Himalayan metamorphism and its tectonic implications. An. Rev Earth Planet Sc 42:381-419

Liu Y, Siebel W, Massonne H-J, Xiao X (2007) Geochronological and petrological constraints for the tectonic evolution of the central Greater Himalayan Sequence in the Kharta area, southern Tibet. J Geol 115:215-230

Montel JM (1993) A model for monazite/melt equilibrium and applications to the generation of granitic magmas. Chem Geol 110:127-146

Newton RC, Charlu TV, Kleppa OJ (1980) Thermochemistry of high structural state plagioclases. Geochim Cosmochim Acta 44:933-941

Palin RM, Searle MP, St-Onge MR, Waters DJ, Roberts NMW, Horstwood MSA, Parrish RR, Weller OM, Chen S, Yang J (2014) Monazite geochronology and petrology of kyanite- and sillimanite-grade migmatites from the northwestern flank of the eastern Himalayan syntaxis. Gondwana Res 26:323-347

Patiño Douce AE, Harris N (1998) Experimental constraints on Himalayan anatexis. J Petrol 39:689-710

PognanteU, Benna P (1993) Metamorphic zonation, migmatization and leucogranites along the Everest transect of Eastern Nepal and Tibet: record of an exhumation history. Geol Soc London Sp Publ 74:323-340

Prince C, Harris N, Vance D (2001) Fluid-enhanced melting during prograde metamorphism. J Geol Soc 158:233-242

Roedder E (1979) Fluid inclusions as samples of ore fluids. In H. L. Barnes (Ed.), Geochemistry of hydrothermal ore deposits ( $2^{\text {nd }}$ ed., pp. 684-737). New York: Wiley.

Rosenberg CL, Handy MR (2005) Experimental deformation of partially melted granite revisited: Implications for the continental crust. J Metamorphic Geol 23:19-28

Rubatto D, Chakraborty S, Dasgupta S (2013) Timescales of crustal melting in the Higher Himalayan crystallines (Sikkim, Eastern Himalaya) inferred from trace elementconstrained monazite and zircon chronology. Contrib Mineral Pet 165:349-372

Rudnick RL, Gao S (2014) Composition of the continental crust. In RL Rudnick Ed, Treatise on Geochemistry, $2^{\text {nd }}, 1-51$

Sawyer EW (2010) Migmatites formed by water-fluxed partial melting of a leucogranodiorite 
protolith: microstructures in the residual rocks and source of the fluid. Lithos 116:273-286

1735

2736

4737

5738

6739

7740

8741

742

11743

12744

13745

14746
Sawyer EW (2014) The inception and growth of leucosomes: microstructure at the start of melt segregation in migmatites. J Metamorphic Geol 32:695-712

Searle MP (2010) Low-angle normal faults in the compressional Himalayan orogen; evidence from the Annapurna-Dhaulagiri Himalaya, Nepal. Geosph 6:296-315

Searle MP, Godin L (2003) The South Tibetan Detachment System and the Manaslu Leucogranite: a structural reinterpretation and restoration of the Annapurna-Manaslu Himalaya, Nepal. J Geol 111:505-523

Stepanov AS, Hermann J, Rubatto D, Rapp RP (2012) Experimental study of monazite/melt partitioning with implications for the REE, Th and U geochemistry of crustal rocks. Chem Geol 300-301:200-220

Sun SS, McDonough WF (1989) Chemical and Isotopic Systematics of Oceanic Basalts: Implications for Mantle Composition and Processes. In: Sanders AD, Norry MJ (Eds), Magmatism in the Ocean Basins. Geological Society, London, Special Publications 42, pp. 313-345

Tajčmanová L, Conolly JAD, Cesare B (2009) A thermodynamicmodel for titanium and ferric iron solution in biotite. J Metamorphic Geol 27:153-165

Tian Z, Zhang Z, Dong X (2016) Metamorphism of high-P metagreywacke from the Eastern Himalayan syntaxis: phase equilibria and P-Tpath. J Metamorphic Geol 34:697-718

Thomas R, Klemm W (1997) Microthermometric study of silicate melt inclusions in Variscan granites from SE Germany: volatile contents and entrapment conditions. J Metamorphic Geol 38:1753-1765

Thomen A, Robert F, Remusat L (2014) Determination of the nitrogen abundance in organic materials by NanoSIMS quantitative imaging. J Anal At Spectr 29:512-519

Thompson JB, Hovis GL (1979) Entropy of mixing in sanidine. Am Mineral 64:57-65

Wang JM, Zhang JJ, Wang XX (2013) Structural kinematics, metamorphic P-T profiles and zircon geochronology across the Greater Himalayan Crystalline Complex in south-central Tibet: implication for a revised channel flow. J Metamorphic Geol 31:607-628

Wang JM, Rubatto D, Zhang JJ (2015) Timing of partial melting and cooling across the Greater Himalayan Crystalline Complex (Nyalam, Central Himalaya): in-sequence Thrusting and its Implications. J Petrol 56/9, 1677-1702

Watson EB, Harrison TM (1984). Accessory minerals and the geochemical evolution of crustal magmatic systems: a summary and prospectus of experimental approaches. Phys Earth Planet Inter 35:19-30.

Weinberg (2016) Geology and tectono-metamorphic evolution of the Himalayan metamorphic core: insights from the Mugu Karnali transect, Western Nepal (Central Himalaya). J Metamorphic Geol 35:301-325

Weinberg R, Hasalová P (2015a) Water-fluxed melting of the continental crust: a review. Lithos 212-215:158-188.

Weinberg R, Hasalová P (2015b) Reply to comment by JD Clemens and G. Stevens on "Water-fluxed melting of the continental crust: A review". Lithos 234:102-103

Weinberg R, Searle MP (1999) Volatile-assisted intrusion and autometasomatism of leucogranites in the Khumbu Himalaya, Nepal. J Geol 107:27-48

White RW, Powell R, Holland TJB (2007) Progress relating to calculation of partial melting equilibria for metapelites. J Metamorphic Geol 25, 511-527

White RW, Powell R, Holland TJB, Worley BA (2000) The effect of $\mathrm{TiO}_{2}$ and $\mathrm{Fe}_{2} \mathrm{O}_{3}$ on metapelitic assemblages at greenschist and amphibolite facies conditions: mineral equilibria calculations in the system $\mathrm{K} 2 \mathrm{O}-\mathrm{FeO}-\mathrm{MgO}-\mathrm{Al}_{2} \mathrm{O}_{3}-\mathrm{SiO}_{2}-\mathrm{H}_{2} \mathrm{O}-\mathrm{TiO}_{2}-\mathrm{Fe}_{2} \mathrm{O}_{3}$. J Metamorphic Geol 18:497-511

White RW, Stevens G, Johnson TE (2011) Is the crucible reproducible? Reconciling melting 
experiments with thermodynamic calculations. Elements 7:241-246

White RW, Powell R, Holland TJB, Johnson TE, Green ECR (2014a) New mineral activitycomposition relations for thermodynamic calculations in metapelitic systems. $\mathrm{J}$ Metamorphic Geol 32:261-286

Yakymchuk C (2017) Behaviour of apatite during partial melting of metapelites and consequences for prograde suprasolidus monazite growth. Lithos 274-275:412-426

Yakymchuk C, Brown M (2014) Behaviour of zircon and monazite during crustal melting. J Geol Soc 171:465-479

Zeng LS, Gao LE, Xie KJ, Liu-Zeng J (2011) Mid-Eocene high Sr/Y granites in the Northern Himalayan Gneiss Domes: melting thickened lower continental crust. Earth Planet Sci Lett 303:251-266

Zeng LS, Liu J, Gao LE, Xie KJ, Wen L (2009) Early Oligocene crustal anatexis in the Yardoi gneiss dome, southern Tibet and geological implications. Chin Sci Bull 54:104112

Zhang H, Harris N, Parrish R, Kelley S, Zhang L, Rogers N, Argles T, King J (2004) Causes and consequences of protracted melting of the mid-crust exposed in the North Himalayan antiform. Earth Planet Sci Lett 228:195-212

Zhang ZM, Zhao GC, Santosh M, Wang JL, Dong X, Liou JG (2010) Two stages of granulite facies metamorphism in the eastern Himalayan syntaxis, south Tibet: petrology, zircon geochronology and implications for the subduction of Neo-Tethys and the Indian continent beneath Asia. J Metamorphic Geol 28:719-733

Zhang Z, Xiang H, Dong X, Ding H, He Z (2015) Long-lived high-temperature granulite-facies metamorphism in the Eastern Himalayan orogen, south Tibet. Lithos 212-215:1-15

Zhang Z, Xiang H, Dong X, Li W, Ding H, Gou Z, Tian Z (2017) Oligocene HP metamorphism and anatexis of the Higher Himalayan Crystalline Sequence in Yadong region, east-central Himalaya. Gondwana Res 41:173-187 


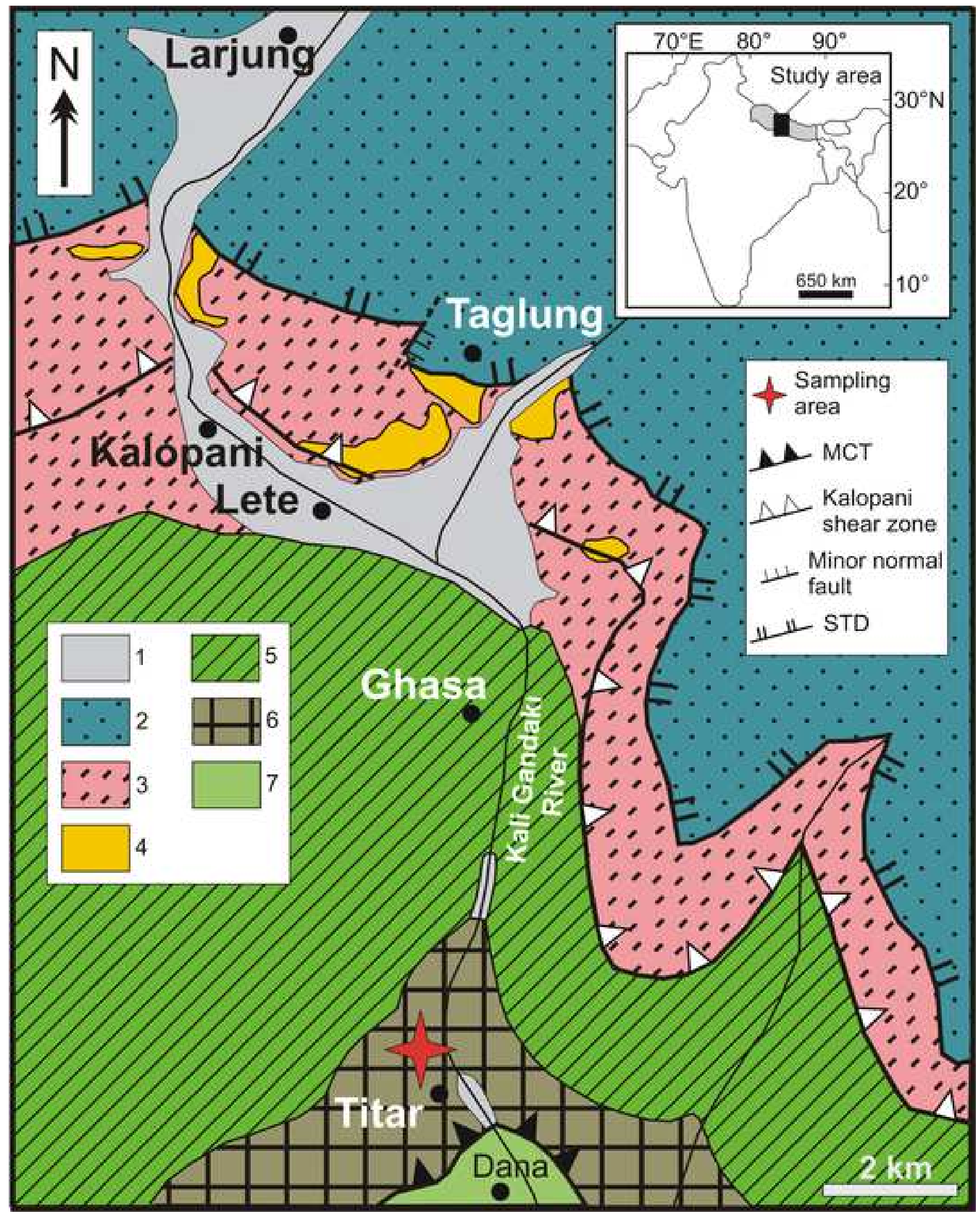



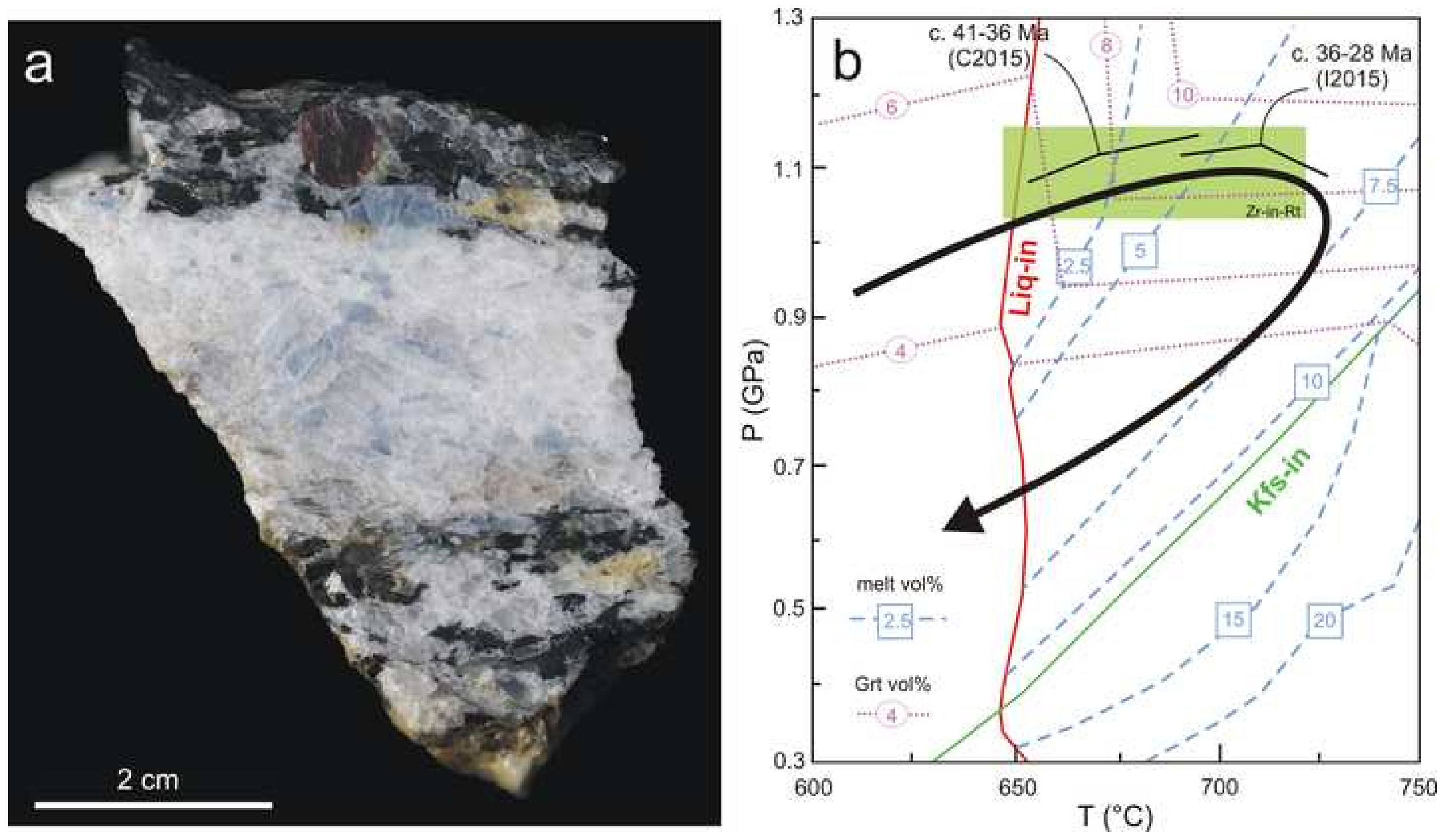

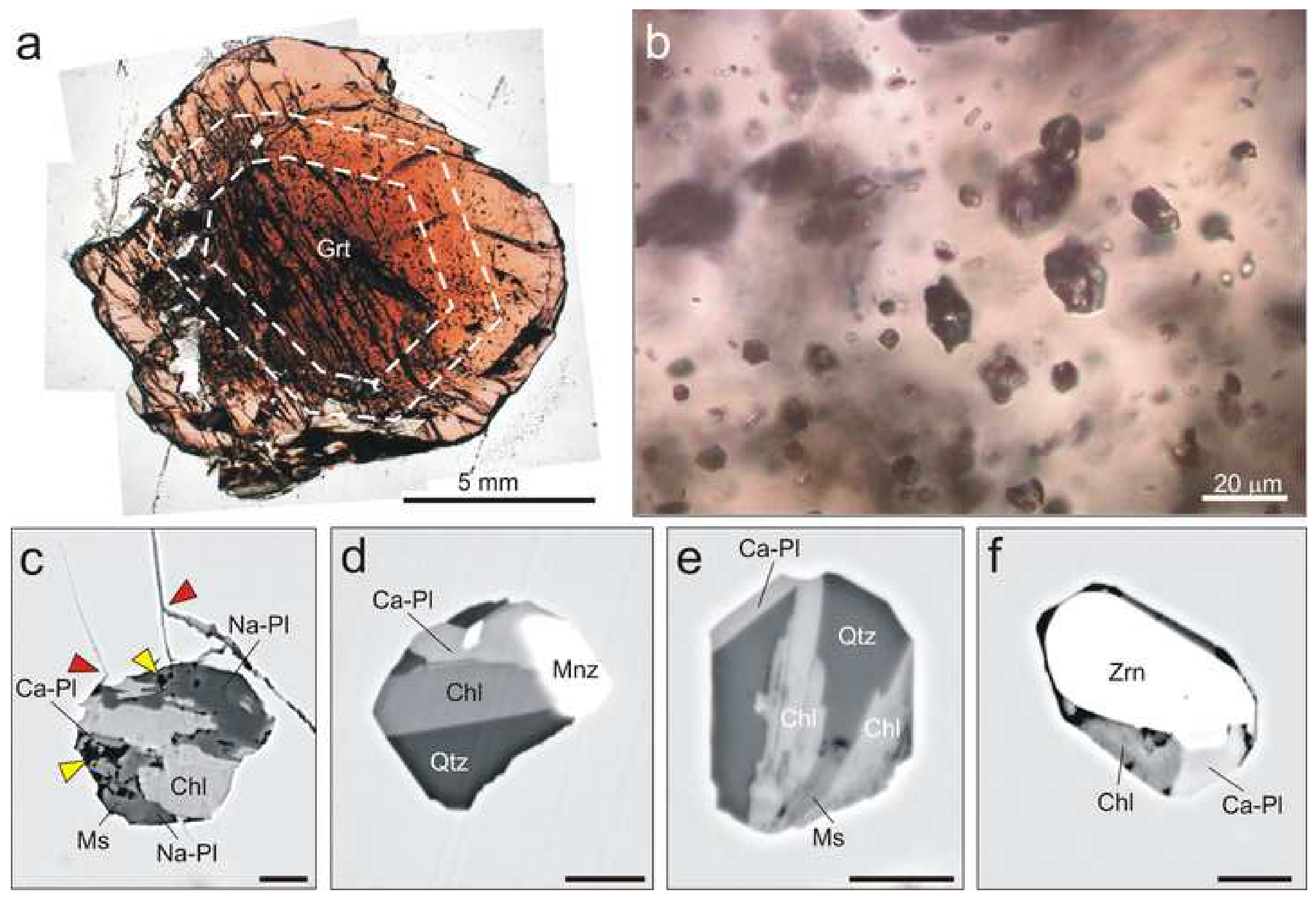


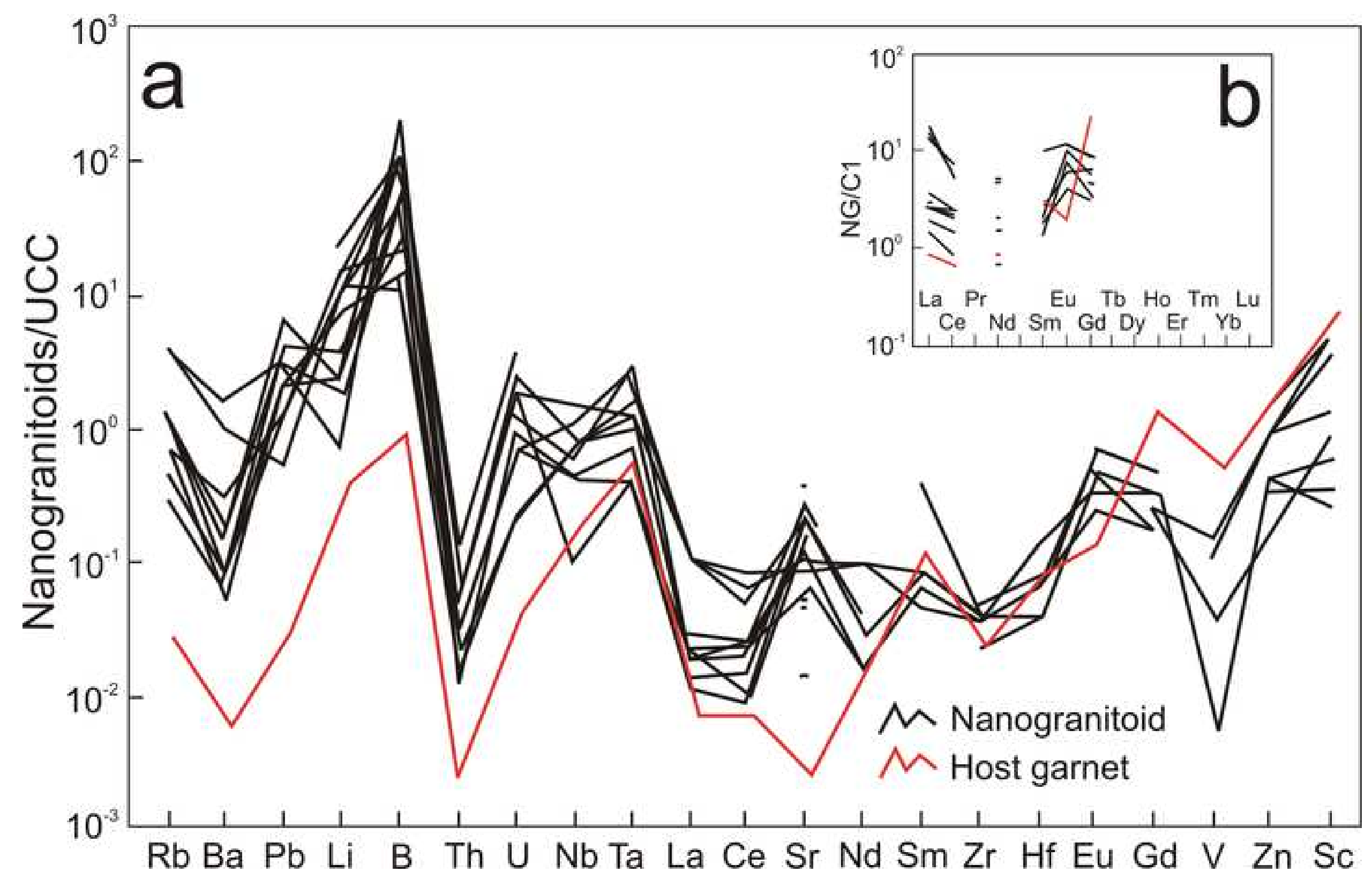




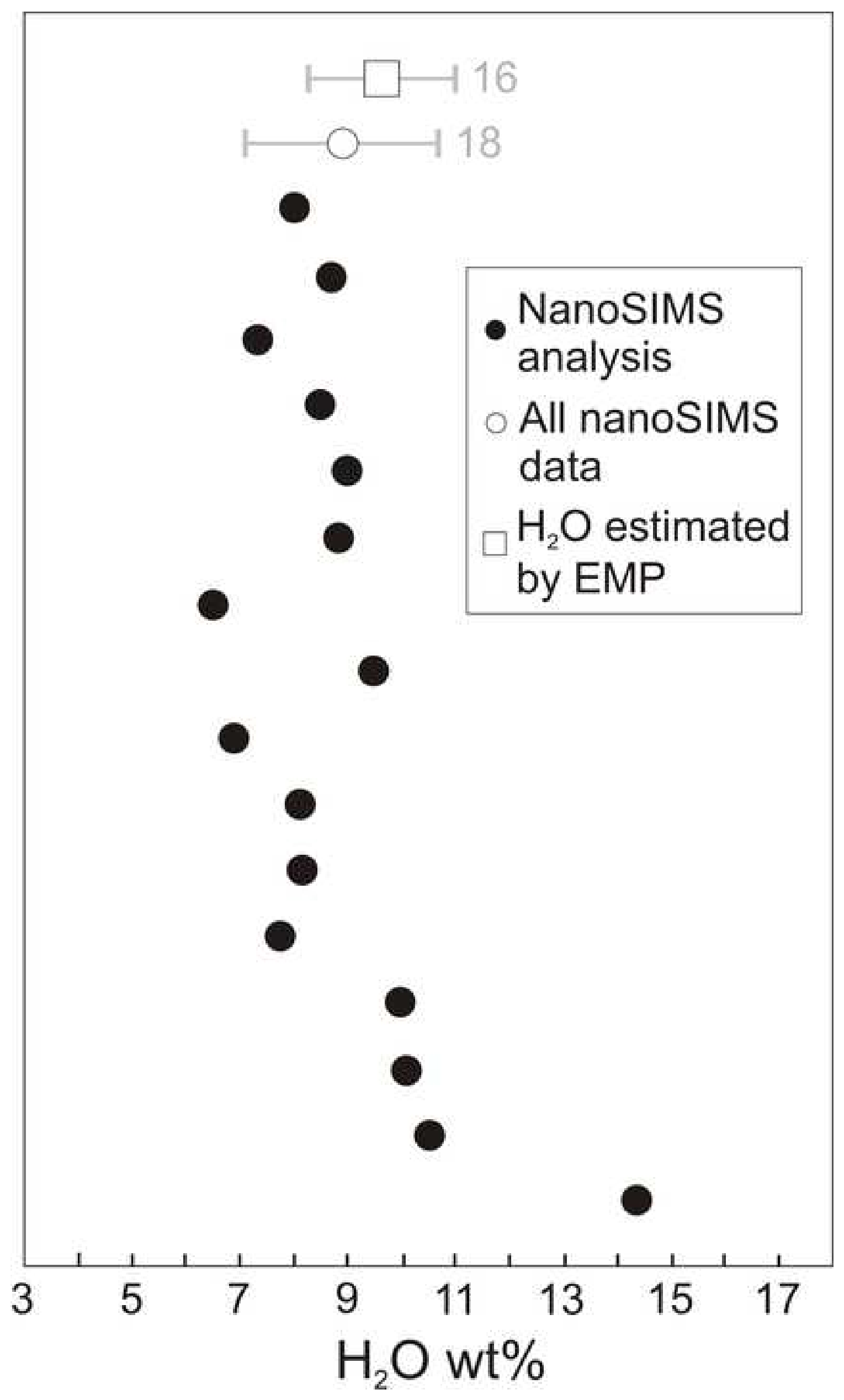

Figure 5

\section{- NanoSIMS analysis} - All nanoSIMS data $\mathrm{H}_{2} \mathrm{O}$ estimated by EMP 


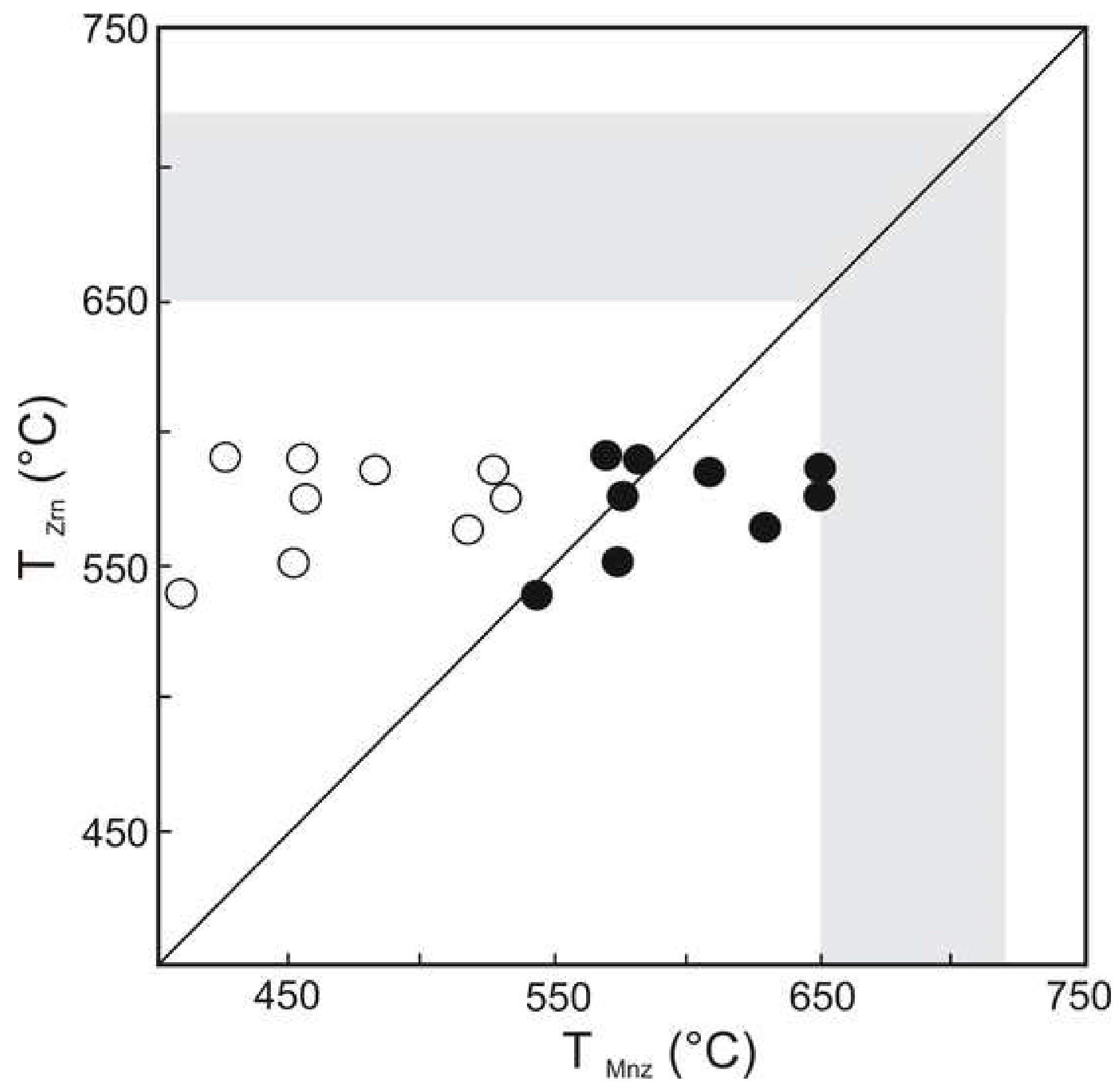



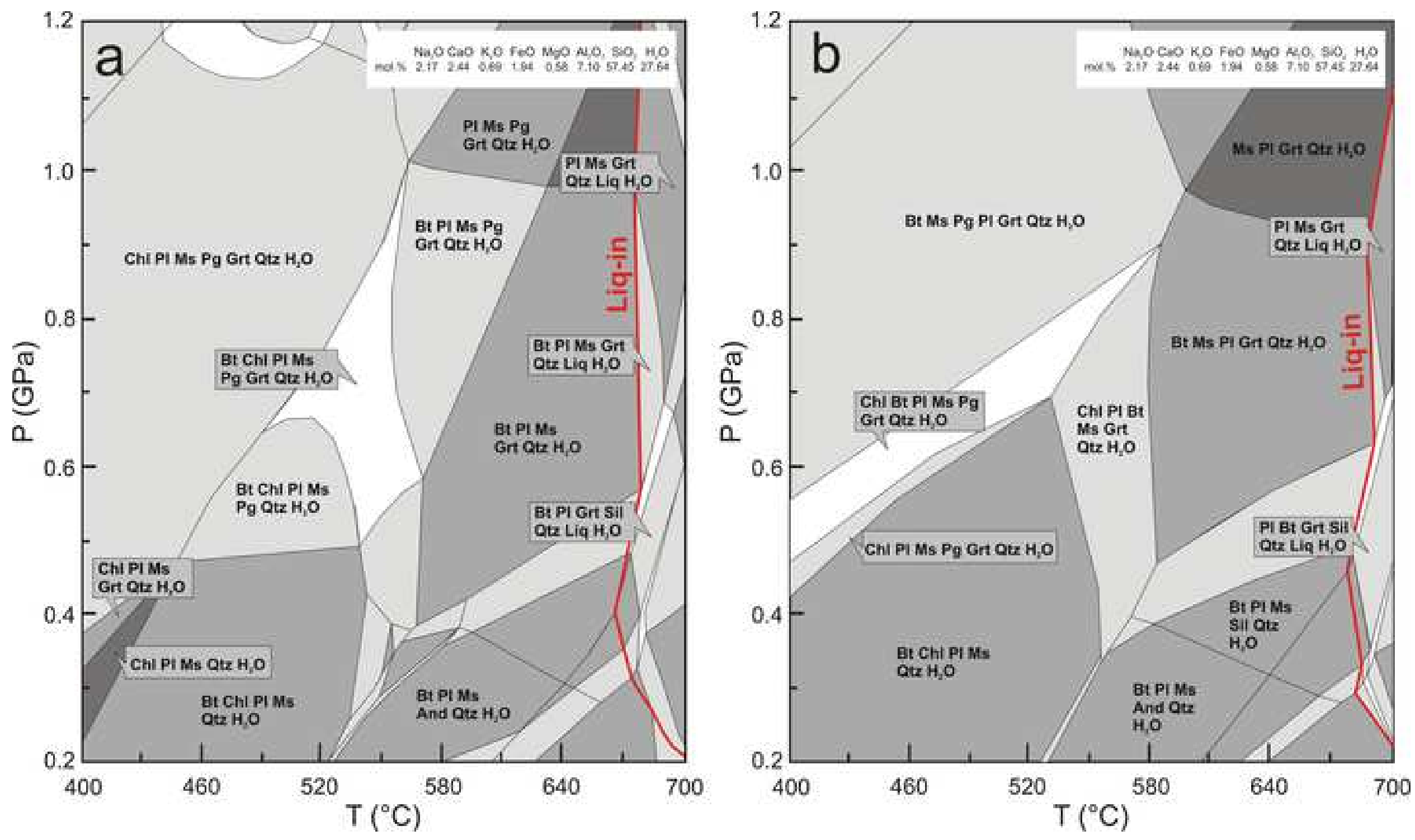


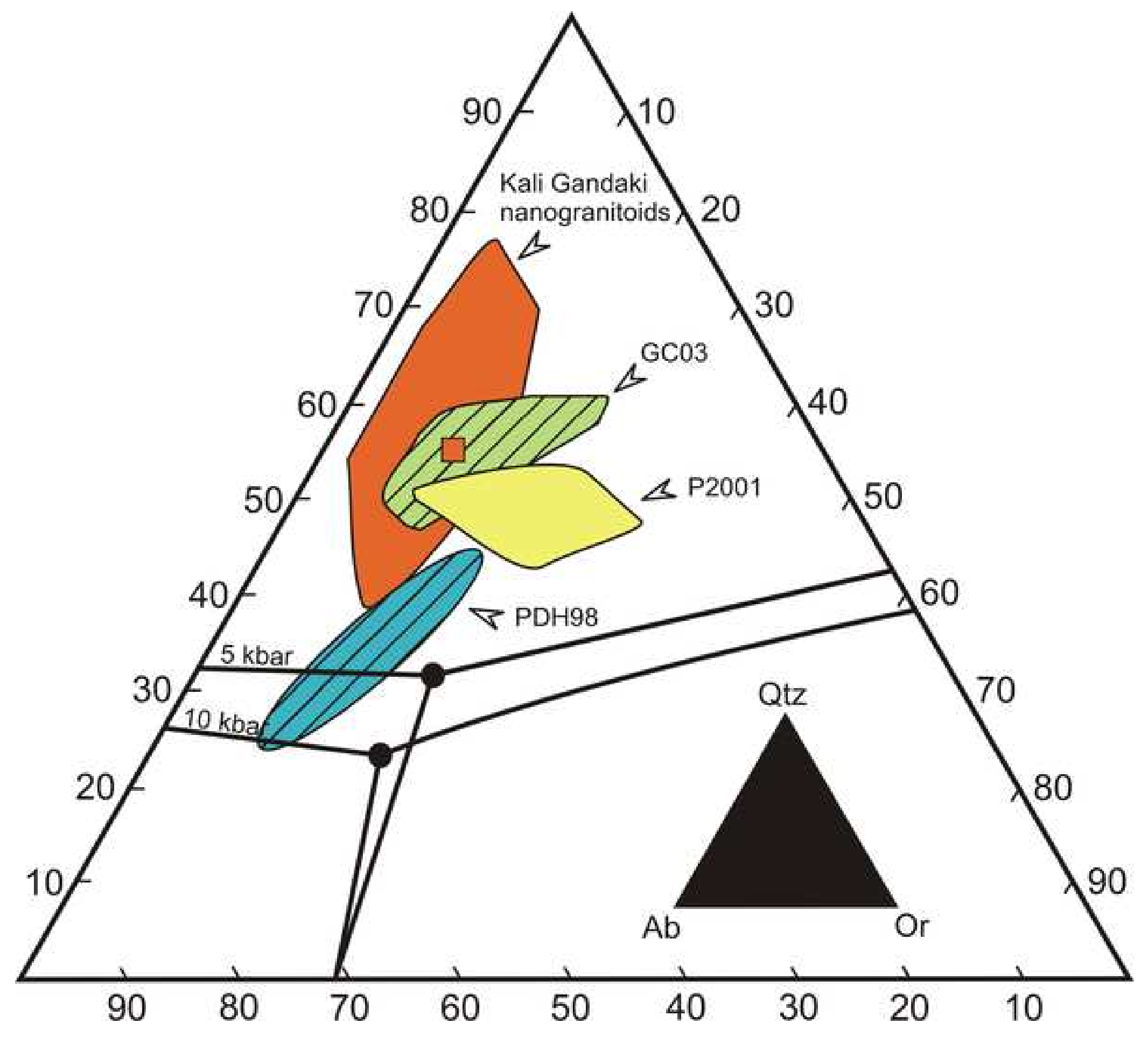



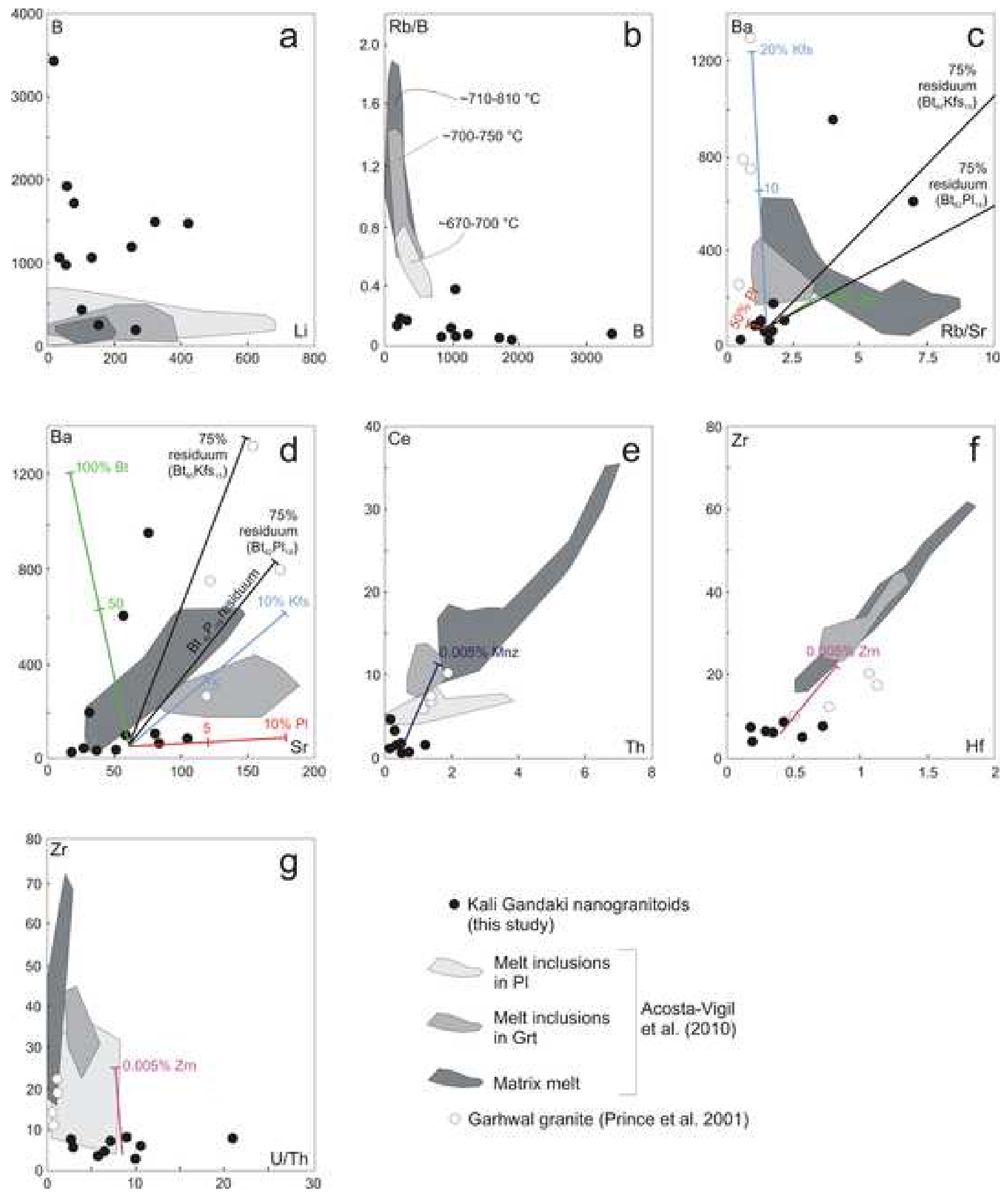

- Kali Gandaki nanogranitoids (this study)

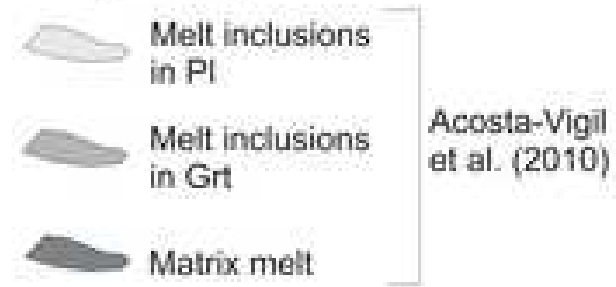

Gartwal granite (Prince et al, 2001) 


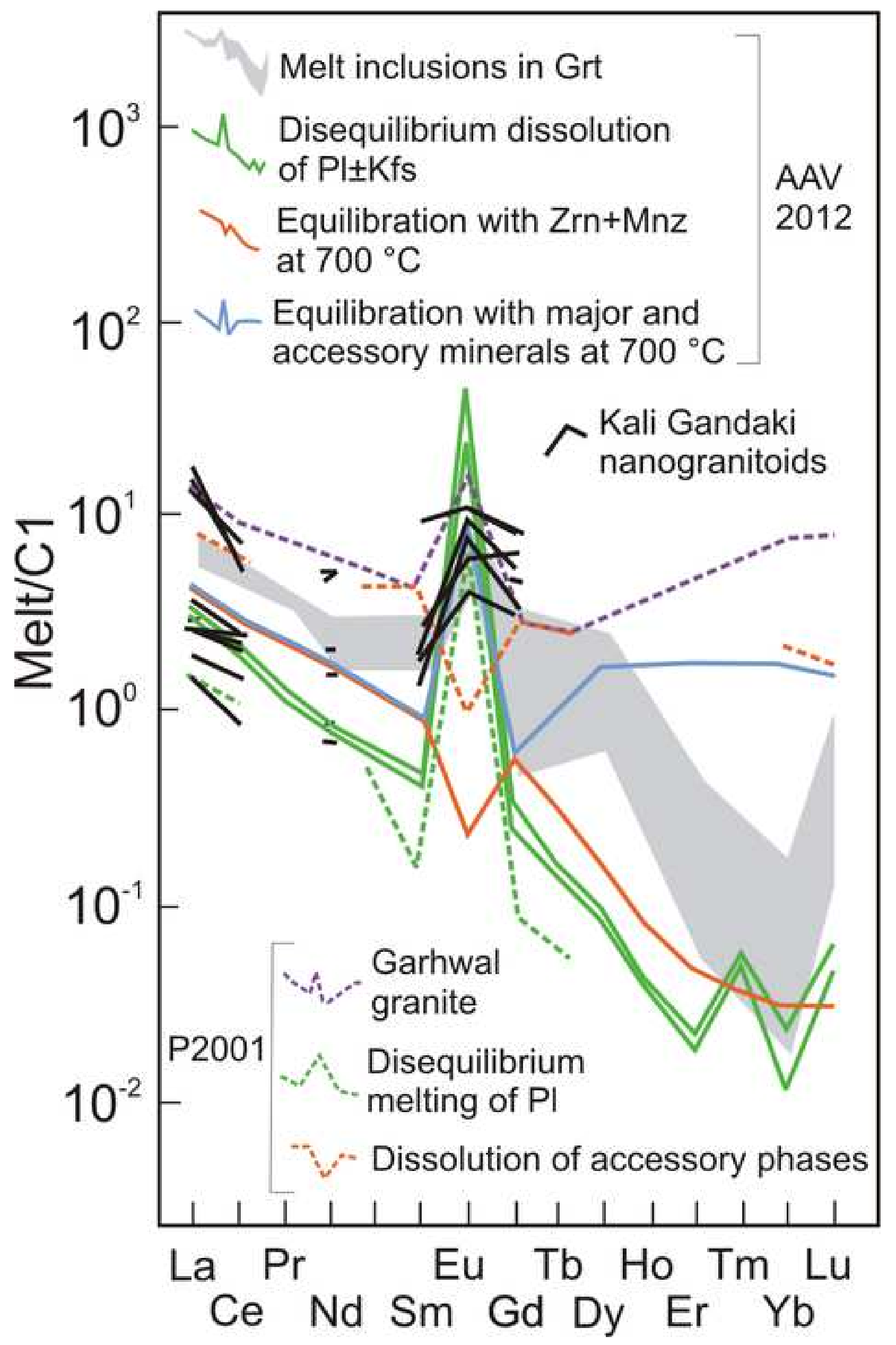


Table 1. LA-ICP-MS analyses (ppm) of melt inclusions and garnet from Kali Gandaki

\begin{tabular}{lrrrrrrrr}
\hline & KGD_27 & KGD_29 & KGD_32 & KGD_38 & KGD_39 & KGD_40 & KGD_45 & KGD_46 \\
$\mathrm{Rb}$ & 103 & 59 & 81 & 127 & 60 & 28 & 43 & 46 \\
$\mathrm{Ba}$ & 77 & 32 & 42 & 101 & 185 & 44 & 50 & 50 \\
$\mathrm{~Pb}$ & 60 & 36 & 47 & 88 & 20 & 20 & 37 & 37 \\
$\mathrm{Li}$ & 79 & 58 & 41 & 50 & 329 & 262 & 153 & 153 \\
$\mathrm{~B}$ & 1731 & 847 & 1068 & 1005 & 325 & 191 & 244 & 242 \\
$\mathrm{Th}$ & 1.2 & 0.48 & 0.68 & 0.48 & 0.43 & 0.32 & 0.20 & 0.17 \\
$\mathrm{U}$ & 8.5 & 5.0 & 6.1 & 4.8 & 3.4 & 1.9 & 0.56 & 0.50 \\
$\mathrm{Nb}$ & b.d.I. & 18.28 & 8.9 & 1.1 & 7.3 & 4.8 & 8.5 & 8.3 \\
$\mathrm{Ta}$ & b.d.I. & 1.2 & 0.86 & 0.33 & 2.6 & 0.31 & 1.2 & 1.1 \\
$\mathrm{La}$ & 0.91 & 0.61 & 0.70 & 0.34 & 0.57 & 0.59 & 3.4 & 3.3 \\
$\mathrm{Ce}$ & 1.7 & 1.3 & 0.54 & 0.53 & 1.5 & 1.4 & 4.0 & 4.8 \\
$\mathrm{Sr}$ & 84 & 37 & 53 & 59 & 34 & 18 & 29 & 27 \\
$\mathrm{Nd}$ & b.d.I. & 0.41 & b.d.I. & b.d.I. & b.d.I. & 0.33 & 2.50 & 2.48 \\
$\mathrm{Sm}$ & 1.7 & 0.29 & b.d.I. & b.d.I. & b.d.I. & b.d.I. & 0.32 & 0.22 \\
$\mathrm{Zr}$ & 7.3 & 6.2 & 8.2 & 3.2 & b.d.I. & 3.9 & 7.5 & 6.2 \\
$\mathrm{Hf}$ & b.d.I. & 0.34 & 0.42 & b.d.I. & b.d.I. & 0.19 & 0.18 & 0.29 \\
$\mathrm{Eu}$ & 0.72 & 0.23 & 0.67 & b.d.I. & b.d.I. & b.d.I. & 0.51 & 0.45 \\
$\mathrm{Gd}$ & 1.9 & 0.68 & 1.9 & 0.96 & b.d.I. & 0.96 & 1.3 & 0.77 \\
$\mathrm{~V}$ & b.d.I. & b.d.I. & b.d.I. & 13 & 20 & 2.7 & 0.43 & b.d.I. \\
$\mathrm{Zn}$ & 61 & 30 & 92 & 62 & b.d.I. & 14 & 26 & 23 \\
$\mathrm{Sc}$ & 66 & 8.0 & 57 & 44 & 76 & 13 & 3.1 & 4.5 \\
$\mathrm{U} / \mathrm{Th}$ & 7 & 11 & 9 & 10 & 8 & 6 & 3 & 3 \\
$\mathrm{Rb} / \mathrm{Sr}$ & 1.2 & 1.6 & 1.5 & 2.2 & 1.8 & 1.6 & 1.5 & 1.7 \\
$\mathrm{Nb} /$ Ta & & 15.2 & 10.3 & 3.2 & 2.8 & 15.5 & 6.8 & 7.9 \\
$\mathrm{Eu} /$ Eu* & 1.2 & 1.6 & & & & & 2.5 & 3.3 \\
\hline $\mathrm{b} . d .1 .:$ below detection limit. n.c.: not considered. *) nanogranitoid containing accidentally tI
\end{tabular}




\begin{tabular}{|c|c|c|c|c|c|c|c|c|}
\hline KGD_58 & KGD_77 & D_03* & D_16* & D_08* & D_11* & _12* & D_34* & D_37* \\
\hline 400 & 305 & b.d.l. & b.d.l. & b.d.I. & b.d.I. & b.d.I. & 104 & 104 \\
\hline 606 & 956 & b.d.l. & b.d.l. & b.d.I. & b.d.I. & b.d.I. & 85 & 105 \\
\hline 9.6 & 49 & n.c. & n.c. & n.c. & n.c. & n.c. & n.c. & n.c. \\
\hline 135 & 18 & 424 & 324 & b.d.l. & 102 & 256 & 58 & b.d.l. \\
\hline 1054 & 3412 & 1485 & 1500 & 1604 & 413 & 1195 & 1914 & 1245 \\
\hline 0.27 & 0.12 & n.c. & n.c. & n.c. & n.c. & n.c. & n.c. & n.c. \\
\hline 1.8 & 2.5 & n.c. & n.c. & n.c. & n.c. & n.c. & n.c. & n.c. \\
\hline 10.7 & 5.5 & n.c. & n.c. & n.c. & n.c. & n.c. & n.c. & n.c. \\
\hline 2.1 & 0.64 & n.c. & n.c. & n.c. & n.c. & n.c. & n.c. & n.c. \\
\hline 4.0 & 0.43 & b.d.l. & b.d.I. & n.c. & n.c. & n.c. & n.c. & b.d.l. \\
\hline 3.3 & 0.88 & n.c. & n.c. & n.c. & n.c. & n.c. & n.c. & n.c. \\
\hline 57 & 76 & b.d.I. & b.d.I. & 15 & 4.4 & 16 & 106 & 81 \\
\hline 0.95 & 0.69 & b.d.I. & b.d.I. & n.c. & n.c. & n.c. & n.c. & b.d.I. \\
\hline b.d.l. & 0.41 & n.c. & n.c. & n.c. & n.c. & n.c. & n.c. & n.c. \\
\hline 4.9 & 7.8 & n.c. & n.c. & n.c. & n.c. & n.c. & n.c. & n.c. \\
\hline 0.56 & 0.71 & n.c. & n.c. & n.c. & n.c. & n.c. & n.c. & n.c. \\
\hline b.d.I. & 0.33 & b.d.l. & b.d.I. & n.c. & n.c. & n.c. & n.c. & b.d.I. \\
\hline b.d.I. & 1.3 & n.c. & n.c. & n.c. & n.c. & n.c. & n.c. & n.c. \\
\hline 10.2 & b.d.I. & n.c. & n.c. & n.c. & n.c. & n.c. & n.c. & n.c. \\
\hline 54 & 48 & n.c. & n.c. & n.c. & n.c. & n.c. & n.c. & n.c. \\
\hline 16 & 34 & n.c. & n.c. & n.c. & n.c. & n.c. & n.c. & n.c. \\
\hline 6 & 21 & & & & & & & \\
\hline 7.0 & 4.0 & & & & & & 1.0 & 1.3 \\
\hline \multirow[t]{2}{*}{5.0} & 8.5 & & & & & & & \\
\hline & 1.4 & & & & & & & \\
\hline
\end{tabular}

apped minerals (e.g., zircon, monazite, rutile) 


\begin{tabular}{r}
\hline garnet \\
1.98 \\
3.48 \\
0.39 \\
7.06 \\
12.7 \\
0.02 \\
0.10 \\
1.89 \\
0.43 \\
0.19 \\
0.40 \\
0.72 \\
0.40 \\
0.45 \\
3.66 \\
0.35 \\
0.12 \\
4.31 \\
44.2 \\
77.4 \\
87.1 \\
\end{tabular}


Table 2 . $\mathrm{H} 2 \mathrm{O}$ concentrations measured in nanogranitoids by NanoSIMS

\begin{tabular}{lcc}
\hline Sample & Water content $(w \mathrm{w} \%)$ & $1 \sigma$ error \\
\hline KGD_1 & 14.4 & 0.1 \\
KGD_2 & 10.5 & 0.1 \\
KGD_3 & 10.1 & 0.1 \\
KGD_4 & 10.0 & 0.1 \\
KGD_5 & 7.7 & 0.1 \\
KGD_6 & 8.1 & 0.1 \\
KGD_7 & 8.1 & 0.1 \\
KGD_8 & 6.9 & 0.1 \\
KGD_9 & 9.5 & 0.1 \\
KGD_10 & 6.5 & 0.1 \\
KGD_11 & 8.8 & 0.1 \\
KGD_12 & 8.9 & 0.1 \\
KGD_13 & 8.4 & 0.1 \\
KGD_14 & 7.3 & 0.1 \\
KGD_15 & 8.7 & 0.1 \\
KGD_16 & 8.0 & 0.1 \\
\hline
\end{tabular}

${ }^{c}$ Average value and $1 \sigma$ standard deviation (in parentheses) regarding all the measurments

${ }^{\mathrm{d}}$ Water contents determined by difference of EMP totals from $100 \%$ 